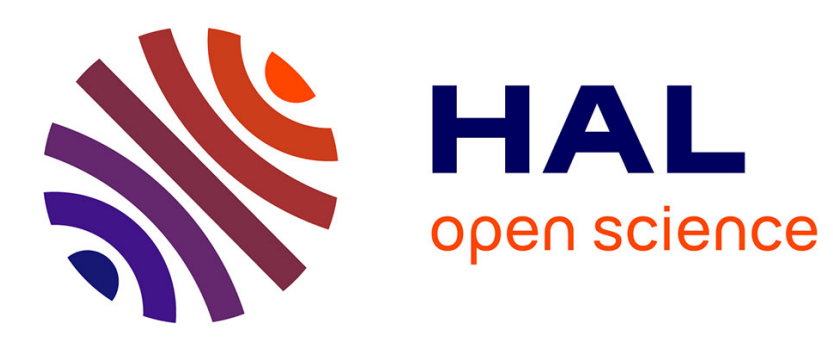

\title{
Petrogenesis of crustal wehrlites in the Oman ophiolite: Experiments and natural rocks
}

J. Koepke, S. Schoenborn, M. Oelze, H. Wittmann, S. T. Feig, E. Hellebrand, Françoise Boudier, R. Schoenberg

\section{> To cite this version:}

J. Koepke, S. Schoenborn, M. Oelze, H. Wittmann, S. T. Feig, et al.. Petrogenesis of crustal wehrlites in the Oman ophiolite: Experiments and natural rocks. Geochemistry, Geophysics, Geosystems, 2009, 10, pp.Q10002. 10.1029/2009GC002488 . hal-00429373

\section{HAL Id: hal-00429373 https://hal.science/hal-00429373}

Submitted on 20 Dec 2021

HAL is a multi-disciplinary open access archive for the deposit and dissemination of scientific research documents, whether they are published or not. The documents may come from teaching and research institutions in France or abroad, or from public or private research centers.
L'archive ouverte pluridisciplinaire HAL, est destinée au dépôt et à la diffusion de documents scientifiques de niveau recherche, publiés ou non, émanant des établissements d'enseignement et de recherche français ou étrangers, des laboratoires publics ou privés.

$$
\text { Copyright }
$$




\title{
Petrogenesis of crustal wehrlites in the Oman ophiolite: Experiments and natural rocks
}

\author{
J. Koepke, S. Schoenborn, M. Oelze, and H. Wittmann \\ Institut für Mineralogie, Leibniz University Hannover, Callinstrasse 3, D-30167 Hannover, Germany \\ (koepke@mineralogie.uni-hannover.de)
}

S. T. Feig

CODES, University of Tasmania, Hobart, Australia

E. Hellebrand

SOEST, Department of Geology and Geophysics, University of Hawaii at Manoa, Honolulu, Hawaii 96822, USA

\section{F. Boudier}

Géosciences Montpellier, Université Montpellier 2, Montpellier, France

\section{R. Schoenberg \\ Centre for Geobiology and Department of Earth Science, University of Bergen, Bergen, Norway}

[1] In the Wadi Haymiliyah of the Oman ophiolite (Haylayn block), discordant wehrlite bodies ranging in size from tens to hundreds of meters intrude the lower crust at different levels. We combined investigations on natural wehrlites from the Wadi Haymiliyah section with an experimental study on the phase relations in a wehrlitic system in order to constrain the petrogenesis of the crustal wehrlites of the Oman ophiolite. Secondary ion mass spectrometry analyses of clinopyroxenes from different wehrlite bodies imply that the clinopyroxenes were crystallized from tholeiitic, mid-ocean ridge (MORB)-type melts. The presence of primary magmatic amphiboles in some wehrlites suggests a formation under hydrous conditions. Significantly enhanced ${ }^{87} \mathrm{Sr} /{ }^{86} \mathrm{Sr}$ isotope ratios of separates from these amphiboles imply that the source of the corresponding magmatic fluids was either seawater or subduction zone-related. The experiments revealed that under wet conditions at relatively low temperatures, a MORB magma has the potential to produce wehrlite in the ocean crust by accumulation of early olivine and clinopyroxene. These show typically high $\mathrm{Mg \#}$ which is a consequence of the oxidizing effect of the prevailing high $a \mathrm{H}_{2} \mathrm{O}$. First plagioclases crystallizing after clinopyroxene under wet conditions are high in An content, in contrast to the corresponding dry system. Trace element compositions of clinopyroxenes of those wehrlites from the Moho transition zone are too depleted in HREE to be in equilibrium with present-day MORB, implying a genetic relation to the V2 lavas of the Oman ophiolite, which are interpreted to be the result of fluidenhanced melting of previously depleted mantle. We present a model on the petrogenesis of the crustal wehrlites in an upper mantle wedge above an initial, shallow subduction zone at the beginning of the intraoceanic thrusting.

Components: 17,481 words, 11 figures, 6 tables.

Keywords: wehrlites; Oman ophiolite; oceanic crust; experimental petrology; hydrous magmatism. 
Index Terms: 3640 Mineralogy and Petrology: Igneous petrology; 3630 Mineralogy and Petrology: Experimental mineralogy and petrology; 1021 Geochemistry: Composition of the oceanic crust; 3618 Mineralogy and Petrology: Magma chamber processes (1036); 8416 Volcanology: Mid-oceanic ridge processes $(1032,3614)$.

Received 9 March 2009; Revised 6 August 2009; Accepted 12 August 2009; Published 10 October 2009.

Koepke, J., S. Schoenborn, M. Oelze, H. Wittmann, S. T. Feig, E. Hellebrand, F. Boudier, and R. Schoenberg (2009), Petrogenesis of crustal wehrlites in the Oman ophiolite: Experiments and natural rocks, Geochem. Geophys. Geosyst., 10, Q10002, doi:10.1029/2009GC002488.

\section{Introduction}

[2] Creation of new oceanic crust at mid-ocean ridges is a fundamental geologic process on Earth. Ocean crust formed at fast spreading rates exhibits a relatively uniform seismic stratigraphy [e.g., Canales et al., 2003] and is regarded as layered and relatively homogeneous. According to the "ophiolite model," which is mainly based on studies on the Oman ophiolite, typical fast spread lower oceanic crust consists of a relatively simple "pan cake" sequence of (from bottom to top) the Moho transition zone (MTZ), layered gabbro developing to isotropic gabbros, and sheeted dikes. However, considerable amounts of the "real" lower crust of the Oman ophiolite are much more complicated, characterized by numerous intrusions of different rock types. Among these, the most enigmatic rocks are wehrlites, which consist mainly of olivine and clinopyroxene and can make up more than $20 \%$ of the crust in some areas of the Oman ophiolite [Juteau et al., 1988b; Jousselin and Nicolas, 2000]. Wehrlites are classically interpreted as constituent of the Earth's mantle, often forming intrusives within tectonized, sub-Moho peridotites, observed in many ophiolites, often in association with pyroxenitic lithologies [e.g., Nicolas, 1989]. In the Oman ophiolite, however, individual wehrlitic intrusions can be followed up to the sheeted dike level, often showing specific features not compatible with typical mantle characteristics, like evolved phase compositions, or the presence of amphibole as primary magmatic phase [Juteau et al., 1988b; Adachi and Miyashita, 2003], leading to controversial discussions on the formation of these wehrlites (here named "crustal" wehrlite).

[3] In order to shed light on the petrogenesis of the crustal wehrlites of the Oman ophiolite we performed a study where we combined experimental work using natural wehrlites as starting material with investigations on natural wehrlites from the Wadi Haymiliyah of the Oman ophiolite (Haylayn block, Figure 1).
[4] Wehrlites are peridotitic rocks consisting of olivine and clinopyroxene. They are often interpreted as record of melt accumulation or as product of melt/peridotite interaction in the deeper lithospheric mantle at pressures below the plagioclase stability, reported from the subcontinent mantle [e.g., Shaw et al., 2005; Beard et al., 2007], from mantle from convergent margins [e.g., Peslier et al., 2002; Parkinson et al., 2003], and from the subocean mantle [Arai and Takemoto, 2007]. These wehrlites often show typical mantle textures and fabrics, and have depleted phase compositions (like typical mantle phases, e.g., high $\mathrm{Mg \#}$ in olivine and clinopyroxene, very low $\mathrm{TiO}_{2}$ content in spinels).

[5] Quite different is the formation of those crustal wehrlites occurring in the Moho transition zone (MTZ) or in the plutonic sequence of some ophiolites [e.g., Koga et al., 2001; Parlak et al., 2002; Bagci et al., 2005]. These are typically formed at low crystallization pressures and mostly show a characteristic cumulate texture suggesting that these rocks were formed by the accumulation of olivine and clinopyroxene in shallow crustal magma chambers. This is also expressed in slightly more evolved phase compositions compared to typical mantle wehrlites [e.g., Koga et al., 2001; Parlak et al., 2002; Bagci et al., 2005]. Since plagioclase is generally stable in mid-ocean ridge (MORB)-type systems at shallow pressures, the question arises which mechanism is responsible for the suppression of plagioclase crystallization. Two major processes are discussed: (1) The primary melts interact intensely with peridotite thus lowering the plagioclase stability [e.g., Benn et al., 1988; Girardeau and Francheteau, 1993]; (2) the presence of water in MORB systems prevented the plagioclase crystallization (see below). The latter model seems to be responsible for many wehrlites occurring in the crust of subduction zone-related ophiolites, where a hydrous nature of the primary melts is given by the presence of subduction-related hydrous fluids [e.g., Parlak et al., 2002; Shervais et al., 2004; 


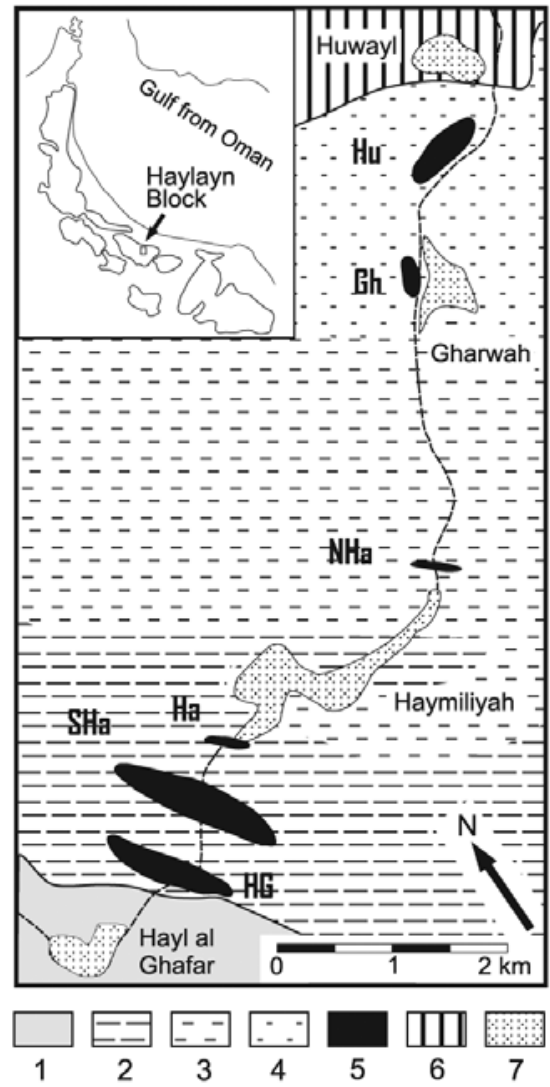

Figure 1. Geological map of the investigated area along the northern Wadi Haymiliyah; simplified according to Nehlig and Juteau [1988]: 1, mantle peridotites; 2 , lower layered gabbros; 3 , layered gabbros intercalated with laminated gabbros; 4, upper layered gabbros and high-level isotropic gabbros; 5, wehrlitic intrusions; 6, sheeted dikes; 7, oases/villages. Marked wehrlite bodies according to Table 1: HG, NE of Hayl al Ghafar; SHa, SW Haymiliyah; Ha, Haymiliyah village; NHa, NE Haymiliyah; Gh, Gharwah; Hu, SW Huwayl. Inset: sketch map of the Oman ophiolite and the location of the studied area within the Haylayn Block. Geographic coordinates of the marked wehrlite bodies are listed in Table 1.

Bagci et al., 2005]. Interestingly, crustal wehrlites are very scarce at mid-ocean ridges in the modern oceans [Girardeau and Francheteau, 1993; Ildefonse et al., 2006].

\section{Wehrlites in the Lower Crust of the Oman Ophiolite}

\subsection{Oman Ophiolite}

[6] The Cretaceous Oman ophiolite is regarded to present the best proxy of fast spreading oceanic crust on land. The relative fast spreading origin is based on the following observations: continuous, typically layered crustal section [Lippard et al., 1986; Nicolas, 1989]; absence of record of typical "amagmatic" spreading as it is common for slow spreading ridges [e.g., Cannat et al., 1995]; very narrow range of zircon crystallization ages across the width of the ophiolite $(\max \sim 100 \mathrm{~km})$ sampled normal to the ridge direction [Tilton et al., 1981; Warren et al., 2005]; spinel $\mathrm{Cr} / \mathrm{Al}$ versus $\mathrm{Mg \#}(=$ $\mathrm{MgO} /(\mathrm{MgO}+\mathrm{FeO})$; molar $)$ ratios, that overlap those for peridotites from modern ridges [Le Mée et al., 2004]; length scale of segmentation and absence of transform faults [MacLeod and Rothery, 1992; Nicolas et al., 2000]; orientation of a welldeveloped sheeted dike sequence perpendicular to the Moho [MacLeod and Rothery, 1992].

[7] Controversial debates are ongoing since decades about whether the ophiolite was formed in a mid-ocean ridge (MOR) or a suprasubduction zone (SSZ) setting. Today, for most scientists the Oman ophiolite is regarded as "somehow" subduction zone-related, but the nature of this subduction zone is still under controversial discussion. For some authors, this subduction zone postdated the ophiolite genesis, and was very shallow dipping, initiated by "hot intraoceanic thrusting" regarded as the first step of obduction (see summary of arguments by Boudier and Nicolas [2007]). For others, the ophiolite originated at a spreading center above a NE dipping subduction zone and the detachment of old, cold oceanic crust was initially steeply dipping to account for the high pressures recorded in the metamorphic sole (see summary of arguments by Warren et al. [2007]). Many scientists believe that the subduction process is responsible for a second stage of magmatism following the major accretion of normal fast spread crust. The majority view is that the volcanic expression of the second stage magmatism corresponds to the "V2" lavas, which are interpreted to be the result from fluid-enhanced melting of previously depleted mantle, and which contrast in composition with the "V1" lavas which resemble modern MORB (for details, references, and nomenclature of the lavas, see Godard et al. [2003]).

\subsection{Crustal Wehrlites in the Oman Ophiolite}

[8] The lower crust of the Oman ophiolite is well known for its heterogeneity expressed by intrusive rocks mainly composed of wehrlites and orthopyroxene-bearing gabbro cutting the layered gabbro sequence, especially in the Northern massifs of the 
Oman ophiolite belt. For the formation of wehrlites quite different models have been proposed. Because of the peridotitic nature of the rocks and high $\mathrm{Mg \#}$ of olivine and clinopyroxene, some authors favor a model that these rocks are directly related to mantle peridotites. According to Benn et al. [1988] the Oman crustal wehrlites represent melt-impregnated mantle peridotites. Another mantle-based model explains the wehrlite formation by the compaction of partly molten asthenospheric diapirs under ridges resulting in upward injection of wehrlitic magmas into the crust [Nicolas and Rabinowicz, 1988; Jousselin and Nicolas, 2000].

[9] Other models are based on the observed cumulate structures and on the chemistry of the phases. According to Juteau et al. [1988b] wehrlites result from mineral accumulation in magmas with picritic composition. On the basis of trace element chemistry in clinopyroxene, Yamasaki et al. [2006] found a strong genetic relation between wehrlites from the Wadi Haymiliyah and corresponding V2 lavas, implying that both belong to a later hydrous magmatism related to a subduction zone following the main magmatism in a normal ridge environment.

[10] Koga et al. [2001] investigated wehrlites from the MTZ level of the Samail massif and showed that their clinopyroxenes were in equilibrium with quite normal MORB melts. This result, however, conflicts with the typical crystallization order observed in MORB systems (plagioclase crystallizes before clinopyroxene) implying that the parental melts were hydrous, since it is well known from experiments in water-rich tholeiitic systems that the crystallization of plagioclase is suppressed [e.g., Gaetani et al., 1993; Feig et al., 2006].

\section{Methods}

\subsection{Electron Microprobe Analysis}

[11] About 2000 single electron microprobe analyses in 27 samples were performed with a Cameca SX100 electron microprobes of the Institut für Mineralogie at the Leibniz University of Hannover equipped with 5 spectrometers and an operating system "Peak sight." All data were obtained using $15 \mathrm{kV}$ acceleration potential, a static (fixed) beam, Ka emission from all elements, and the "PAP" matrix correction [Pouchou and Pichoir, 1991]. Most element concentrations were obtained with a beam current of $15 \mathrm{nA}$ and a counting time of $10 \mathrm{~s}$ on peak and background. For some trace elements in distinct phases we applied higher beam currents $(40 \mathrm{nA})$ and increased counting times (60 to $120 \mathrm{~s})$ leading to more accurate trace element data and lower limits of detection. Limits of detection (in wt $\%$ ): $\mathrm{SiO}_{2}$ in spinels: $0.03 ; \mathrm{TiO}_{2}: 0.03 ; \mathrm{Al}_{2} \mathrm{O}_{3}$ in olivine: $0.02 ; \mathrm{Cr}_{2} \mathrm{O}_{3}$ and $\mathrm{NiO}: 0.04 ; \mathrm{CaO}$ in olivine, spinel: $0.05, \mathrm{Na}_{2} \mathrm{O}: 0.03: \mathrm{K}_{2} \mathrm{O}: 0.02 ; \mathrm{Cl}$ in amphibole: 0.005 ; $\mathrm{F}$ in amphibole: $0.05 ; \mathrm{MgO}$ and $\mathrm{K}_{2} \mathrm{O}$ in plagioclase of profiles (section 7.3): 0.005 .

\subsection{Secondary Ion Mass Spectrometry}

[12] SIMS: Clinopyroxenes of four samples were analyzed by secondary ion mass spectrometry (SIMS) technique at the Max-Planck Institut für Chemie in Mainz, Germany. For analysis conditions, see Hellebrand et al. [2005].

\subsection{Sr Isotopes}

\subsubsection{Separation and Characterization of Amphiboles}

[13] Wehrlites containing poikilitic amphibole were crushed in a rock mill. Amphiboles were preconcentrated from the $125-250 \mu \mathrm{m}$ grain size fraction of the crushed material using a Frantz magnetic separator. Approximately $20 \mathrm{mg}$ of pristine amphiboles without cracks were carefully handpicked and a precleaning step, following the procedure of Bosch et al. [2004], was applied to the sample group " $04-X$ " to ensure high mineral integrity and complete removal of adsorbed secondary microphases. All amphibole separates were checked for purity by backscattered electron microscopy combined with EDX.

\subsubsection{Leaching Procedure}

[14] The necessity for the leaching procedure described by Bosch et al. [2004] following Bosch [1991] to remove traces of late low-temperature seawater alteration was tested by a leaching experiment. For this experiment, sample 04-107 was split into two aliquots; one aliquot (04-107 NL) was processed without leaching, as were all other amphibole separates, while the second aliquot (04-107 LN) was leached in $70^{\circ} \mathrm{C}$ warm $6 \mathrm{M} \mathrm{HCl}$ for $8 \mathrm{~min}$ followed by a $30 \mathrm{~min}$ leach in $70^{\circ} \mathrm{C}$ warm $2.5 \mathrm{M} \mathrm{HCl}$. Three aliquots resulted from this experiment, the first and second liquids extracted after each leach (04-107 LN 1st and 04-107 LN 2nd) and the solid mineral residue (04-107 LN). Leached liquids were dried down and followed by chromatographic $\mathrm{Sr}$ extraction. The solid 
residue was digested similar to all other, unleached samples.

\subsubsection{Sample Digestion}

[15] For sample digestion, approximately $20 \mathrm{mg}$ of mineral concentrates were dissolved in Teflon beakers using a $2: 1$ mixture of $28 \mathrm{M} \mathrm{HF}$ and $15 \mathrm{M}$ $\mathrm{HNO}_{3}$ and heating to $130^{\circ} \mathrm{C}$ for $48 \mathrm{~h}$. After complete dissolution and drying down, the residues were taken up in $8 \mathrm{M} \mathrm{HCl}$ and heated to $150^{\circ} \mathrm{C}$ overnight to destroy remaining fluorides. Upon renewed dry down the samples were dissolved in $2.5 \mathrm{M} \mathrm{HCl}$ and ready for chromatographic extraction of Sr. A two-step procedure was applied to separate strontium from other elements. In a first step, Sr was preconcentrated by conventional cation chromatography using DOWEX 50xW8 resin (200-400 mesh) and $2.5 \mathrm{M} \mathrm{HCl}$ as eluting agent. In the second step, strontium was purified on a microcolumn using approximately $200 \mu \mathrm{l}$ of BioRad Sr Spec resin. After column chromatography, samples were dried down and taken up in $0.3 \mathrm{M} \mathrm{HNO}_{3}$. Each sample was split, one for the determination of $\mathrm{Sr}$ concentrations and the other for $\mathrm{Sr}$ isotope analysis.

\subsubsection{Measurement Procedures}

[16] Sr concentrations were determined by opticalemission spectroscopy (ICP-OES) on a Varian Vista instrument. No Rb signals above detection limits were measured during these analyses. $\mathrm{Sr}$ isotope ratios were determined on a ThermoFinnigan Neptune MC-ICP-MS of the Institut für Mineralogie at the Leibniz University of Hannover in low-resolution mode. Krypton interferences of ${ }^{84} \mathrm{Kr}$ on ${ }^{84} \mathrm{Sr}$ and ${ }^{86} \mathrm{Kr}$ on ${ }^{86} \mathrm{Sr}$ were subtracted by prerun on-peak-zero measurements on blank solutions. Both, ${ }^{82} \mathrm{Kr}$ and ${ }^{83} \mathrm{Kr}$ were monitored during sample analyses and further krypton corrections applied when necessary. NIST SRM 987 measurements performed during the course of this study yielded an average ${ }^{87} \mathrm{Sr} /{ }^{86} \mathrm{Sr}$ ratio of $0.710231 \pm$ 0.000024 . Radiogenic ingrowth of ${ }^{87} \mathrm{Sr}$ from ${ }^{87} \mathrm{Rb}$ for the samples' ages of $\sim 100 \mathrm{Ma}$ is negligible relative to measurement precision. Age corrections for pargasites from Oman gabbros performed by Bosch et al. [2004] were generally below the analytical error because of very low $\mathrm{Rb}$ contents in the amphiboles. Very low Rb contents are also expected for the amphiboles in this study, since the wehrlites can be regarded as similarly refractory than those gabbros used by Bosch et al. [2004].

\subsection{Experimental Techniques}

[17] Crystallization experiments have been conducted in the Institut für Mineralogie at the Leibniz University of Hannover. We used internally heated pressure vessels (IHPV) equipped with rapidquench and redox-control facilities [Berndt et al., 2002] at $200 \mathrm{MPa}$, at temperatures between 1040 and $1200^{\circ} \mathrm{C}$ and at varying water content. To avoid Fe loss to the capsule material, $\mathrm{Au}_{80} \mathrm{Pd}_{20}$ capsules presaturated with $\mathrm{Fe}$ were used. $a \mathrm{H}_{2} \mathrm{O}$ and $\mathrm{fO}_{2}$ (oxygen fugacity) for individual runs were calculated following Berndt et al. [2005]. Since the prevailing $\mathrm{fO}_{2}$ of the water-bearing runs is a function of $a \mathrm{H}_{2} \mathrm{O}$ [e.g., Botcharnikov et al., 2005], $f_{2}$ varied between $\sim \mathrm{QFM}-1$ and $\mathrm{QFM}+1$ for the nominally dry runs $(\mathrm{QFM}=$ quartz fayalite magnetite buffer) and was of QFM + 2 under watersaturated conditions. We chose this value, since it was indicated (section 2.2) that the wehrliteforming magmas showed high water activities, which in turn as a strongly oxidizing effect. A rough estimation based on experimental data of Feig et al. [2006] reveal that a dry MORB melt with a $f \mathrm{O}_{2}$ of $\sim \mathrm{QFM}$ will be shifted to oxidizing conditions of QFM $\sim+2$, just by increasing the water content from nominally dry to a value where water saturation is reached.

[18] Our starting material was a mixture of natural olivines and clinopyroxenes separated from massive wehrlites from the lower Wadi Haymiliyah section, and a synthesized glass representing the "lost" melt that was in equilibrium with the massive wehrlites. As natural rock we chose the very fresh wehrlite 04-73, from which a pure concentrate of olivine and clinopyroxene was separated. The composition of the "lost" equilibrium melt was initially calculated using olivine-melt and cpx-melt distribution coefficients. However, this approach proved extremely difficult, as discussed below.

[19] The most robust parameter for the evaluation of the major composition of the equilibrium melt is the $\mathrm{Kd}_{\mathrm{Mg}-\mathrm{Fe}}$ for olivine/melt. For the corresponding calculation, it is necessary to fix either $\mathrm{FeO}$ or $\mathrm{MgO}$ in the liquid. Results from SIMS data on the clinopyroxenes revealed that the liquid was of primitive tholeiitic composition (see below). Moreover, from the known phase petrology, it is obvious that a high water activity is required to suppress the crystallization of plagioclase (see section 2.2). However, since the addition of water to a hydrogen-buffered magmatic system will shift the redox conditions to 
higher oxygen fugacity, the $\mathrm{FeO} / \mathrm{Fe}_{2} \mathrm{O}_{3}$ ratio of the melt is strongly influenced. At a given forsterite composition of $90 \mathrm{~mol} \%$ (sample 04-73), and a primitive MORB composition as first approximation for the liquid composition (average from Kelemen et al. [2004]), we calculated MgO compositions of the equilibrium liquid by using the $\mathrm{Kd}_{\mathrm{Mg}-\mathrm{Fe}}$ for olivine/melt of 0.32 (the recommended value according to Putirka [2008]) and "true" $\mathrm{FeO}$ contents in the melt by applying the model of Kress and Carmichael [1991]. The resulting $\mathrm{MgO}$ values as function of $f_{2}$ vary considerably between $12.8 \mathrm{wt} \% \mathrm{MgO}$ for the most reducing case (FMQ $-2 ; 1200^{\circ} \mathrm{C}$ ) and $4.7 \mathrm{wt} \%$ for the most oxidizing case (FMQ +4$)$. For $f \mathrm{O}_{2}$ corresponding to $\mathrm{FMQ}+2$, that oxygen fugacity we applied in our experiments, we calculated $9.9 \mathrm{wt} \% \mathrm{MgO}$ for the equilibrium melt. The corresponding $\mathrm{FeO}$ value is $6.1 \mathrm{wt} \%$, and we used these value as $\mathrm{MgO}$ and $\mathrm{FeO}$ content for the synthesis of glass representing the "lost" equilibrium melt.

[20] The approach of using more mineral-melt distribution coefficients for calculating the composition of the "lost" equilibrium melt failed, since Kd's evaluated from appropriate experimental studies varied much to strong within their errors (e.g., variation of $\mathrm{Al}_{2} \mathrm{O}_{3}$ content between 6 and $17 \mathrm{wt} \%)$.

[21] In the absence of any other constraint enabling the evaluation of the composition of the proper equilibrium liquid, we realized that the calculated $\mathrm{MgO}$ and $\mathrm{FeO}$ concentrations (9.9 and $6.1 \mathrm{wt} \%$, respectively) are quite similar to the corresponding values of the starting material used in the experimental investigation of Feig et al. [2006] for their comprehensive systematic study on phase relations in a primitive gabbro $(10.2 \mathrm{wt} \% \mathrm{MgO}, 6.6 \mathrm{wt} \%$ $\mathrm{FeO})$. To benefit from the knowledge on the wellknown phase relations in this system, our next approach was to use the composition of Feig et al. [2006] as composition for the "lost" equilibrium melt. Coherent and reasonable results on phase relations and phase compositions imply that this approach was acceptable, as discussed in section 7.1.

\section{Field Work}

[22] The Wadi Haymiliyah crustal section is well known for its multistage intrusion history, and was studied intensely in the past (for detailed lithological description and for the geologic background, see Juteau et al. [1988b], Nehlig and Juteau [1988], Reuber et al. [1991], Lachize et al. [1996], and
Yamasaki et al. [2006]). Wehrlites occur either as huge, up to several $100 \mathrm{~m}$ thick bodies or as intrusive subconcordant decimeter- to meter-thick sills and plugs. We focused our sampling on individual discordant larger bodies (Figure 1). Their contacts with the host rocks are typically sharp and lobate; chilled margins never appear. Inclusions of layered gabbros are common and may be viscously deformed. In places, the layers of the gabbro at the contact are smoothly deformed and bent according to the intrusive wehrlite, but without any sign of plastic deformation of the involved gabbro minerals. These observations imply that the surrounding gabbros were still very hot during intrusion, with a behavior more of a crystal mush. This observation is of significance, since it makes clear that the wehrlites intruded in the still very hot on-axis environment, but during a late magmatic stage.

[23] It is noteworthy to mention that the overall composition of the surrounding gabbros is changing from the bottom to the top of the crust, both in terms of lithology and of chemical composition. This has consequences for possible crustal contamination effects which may help to explain the observed evolution trend with crustal height as discussed in section 7.2.

\section{Petrography}

[24] A compilation of the petrographic features of individual wehrlite bodies are shown in Table 1. We observed a continuous texture evolution with crustal height: While the rocks from the lower part of the profile show polygonal, equigranular textures, which are in part well equilibrated, the wehrlites from the upper part of the section are typical orthocumulates with a well-developed poikilitic texture. Late orthopyroxene is sometimes present in rocks, but mostly in small amounts. Plagioclase which occurs only in the wehrlites of the upper part of the section, crystallized always very late and interstitially. The crystallization order is typically: $\mathrm{sp} .>\mathrm{ol}=\mathrm{cpx}(>\mathrm{opx})$ in the lower, and sp. $>$ ol $>\operatorname{cpx}(>$ opx $)>$ am $=$ pla in the upper part (for abbreviations and explanation, see Table 1). Two aspects are of significance: (1) Plagioclase, if present, crystallized always after olivine and pyroxene. This is the key observation, leading to the hypothesis that the crustal wehrlites could represent cumulates from hydrous tholeiitic melts which is the rationale behind the experimental work (see below). (2) Many wehrlites from the upper part bear mm-sized poikilitic amphibole 
Table 1. Field Characteristics and Petrographical Features of the Analyzed Samples ${ }^{\mathrm{a}}$

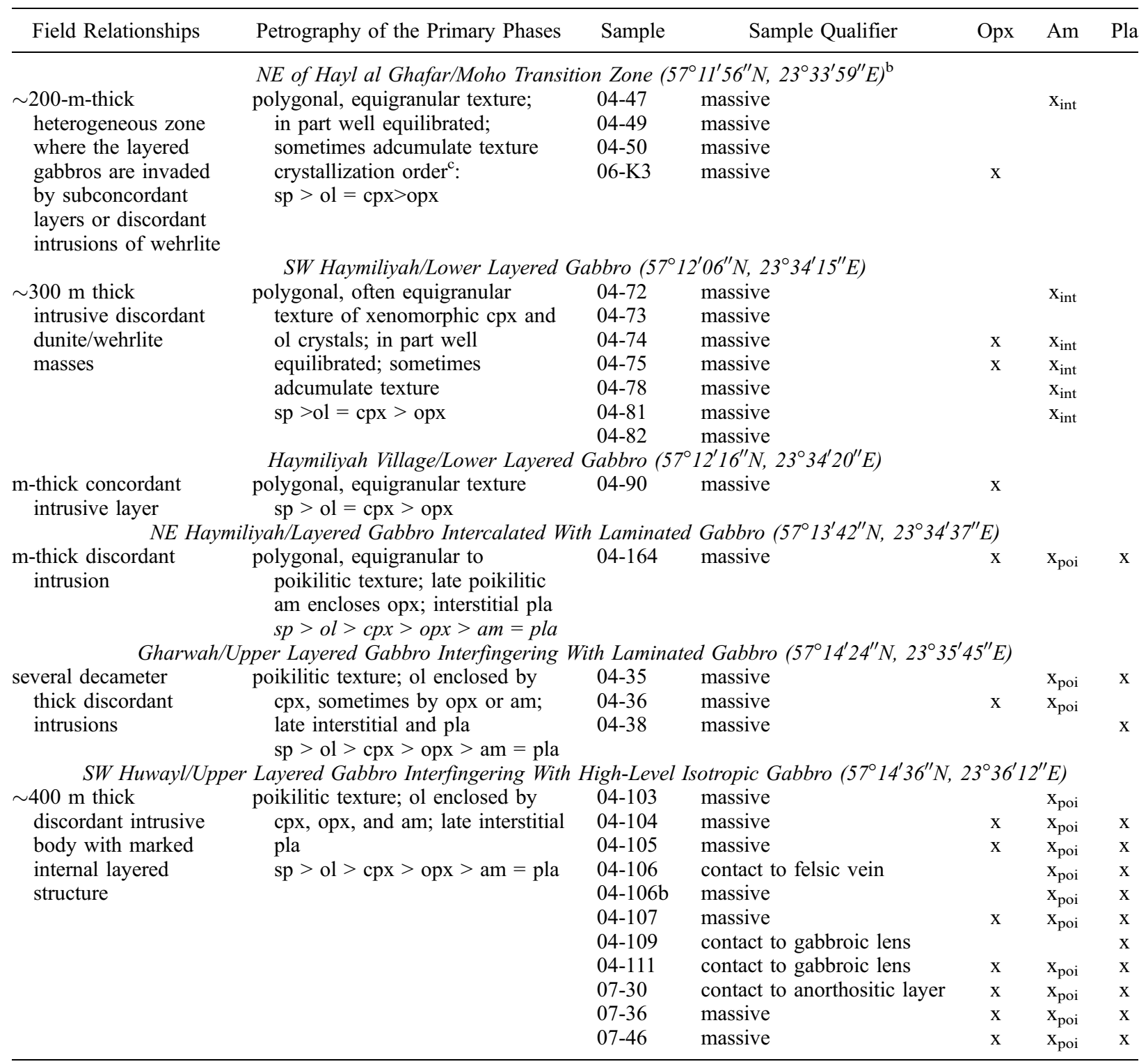

\footnotetext{
${ }^{\mathrm{a}}$ Abbreviations: am, amphibole (int, interstitial; poi, poikilitic); cpx, clinopyroxene; ol, olivine; opx, orthopyroxene; pla, plagioclase; sp, spinel.

${ }^{\mathrm{b}}$ Location/structural level; see geological map in Figure 1. Geographic coordinates are given in lat/lon grid.

${ }^{c}$ Crystallization order: example: $\mathrm{sp}>\mathrm{ol}=\mathrm{cpx}>\mathrm{opx}$ means sp crystallizes first, then $\mathrm{ol}+\mathrm{cpx}$, then opx.
}

(Figure 2). This demonstrates clearly that amphibole was formed during the main stage of crystallization, and not at very late stage under near-solidus conditions where exclusively interstitial crystallization is possible [e.g., Coogan et al., 2001; Koepke et $a l ., 2005 \mathrm{a}]$. This is of importance, since it is a firstorder observation that the corresponding magmas prevailed under high $a \mathrm{H}_{2} \mathrm{O}$ [e.g., Johnson et al., 1994]. Moreover, it limits the temperature of the magma at this crystallization stage to the relatively low value of $\sim 1050^{\circ} \mathrm{C}$, since this is the maximum temperature for amphibole stability observed in basaltic systems at shallow pressure [e.g., Ernst and Liu, 1998].

[25] In some of the wall rock gabbros adjacent to the wehrlites as well as in layered gabbro enclaves within the wehrlites we found typical interstitial parageneses including plagioclase strongly enriched in An coexisting with pargasite, very similar to those observed by Koepke et al., 2004, 2005a. This suggests that hydrous partial melting 

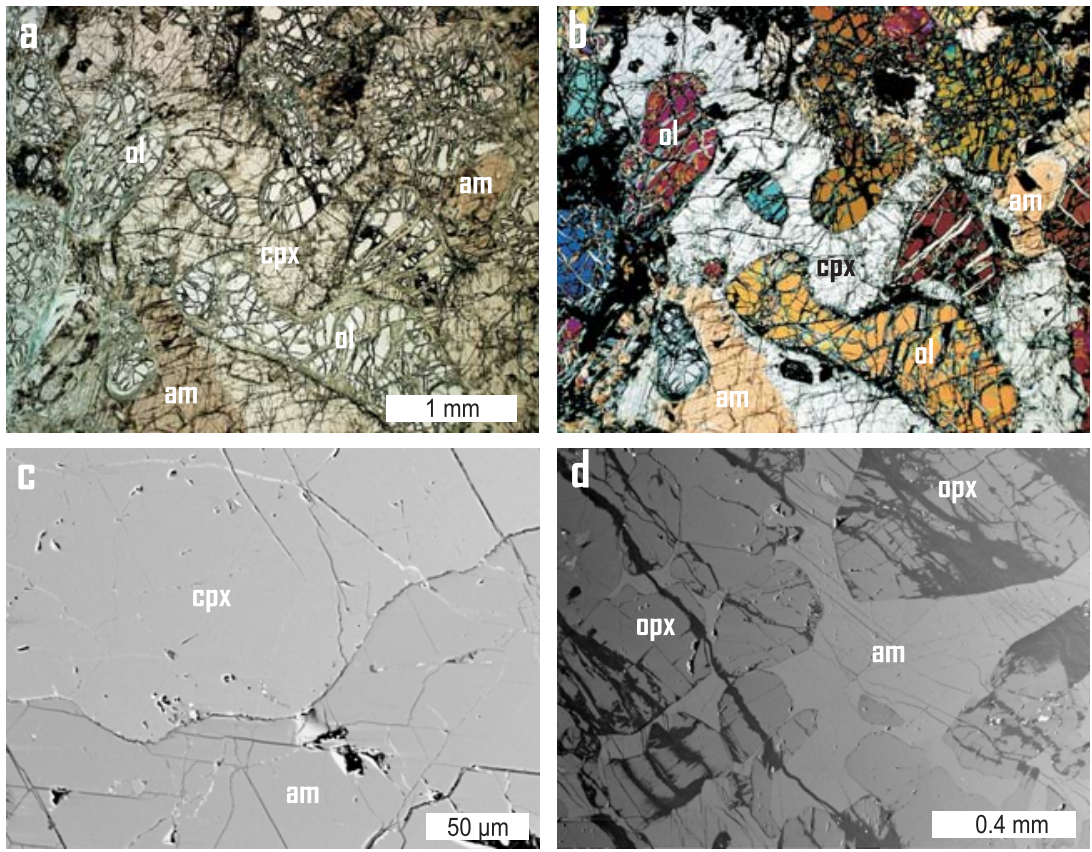

Figure 2. Poikilitic amphibole in massive wehrlites from the upper part of the Wadi Haymiliyah section. Coexisting poikilitic clinopyroxene (cpx) and amphibole (am) enclose olivine (ol) chadacrysts: (a) plane-polarized light and (b) cross-polarized light. (c) BSE image showing the contact between poikilitic cpx and am. The grain boundary is sharp and of lobate style, implying a formation by magmatic growth instead by a late magmatic or postmagmatic high-temperature reaction. (d) BSE image showing poikilitc am enclosing orthopyroxene (opx) chadacrysts. Samples: Figures 2a and 2b, 04-105; Figure 2c, 04-104; Figure 2d, 04-164.

reactions within these gabbros proceeded (see section 7.3).

\section{Results}

\subsection{Major Element Mineral Compositions}

[26] Common feature of all wehrlite bodies is the dominance of high magnesian olivine $\left(\mathrm{Fo}_{86-94}\right)$ and clinopyroxene $\left(\mathrm{Mg} \#_{83-90}\right)$ at all crustal levels (Table A1). Interstitial plagioclase occurring only in the wehrlites of the upper section shows generally high An contents varying between 78 and $89 \mathrm{~mol} \%$. The poikilitic amphiboles of the upper wehrlite bodies are magnesiohastingsites and pargasites thus corresponding to formations at high temperatures. Pyroxenes and amphiboles are high in $\mathrm{Cr}_{2} \mathrm{O}_{3}$ (Table $\mathrm{A} 1$ ), indicating that the parental magmas were primitive.

[27] A clear correlation between mineral composition and crustal height of the different bodies is obvious. For instance, $\mathrm{Mg} \#$ of olivine and pyroxene clearly decreases with crustal height (Figure 3). The correlation is very strong in terms of the minor elements in both clinopyroxene and orthopyroxene
(Figure 3), resulting in homogeneous trends from the bottom to the top of the crustal profile. The observed correlation, together with the textural and trace element mineral trends (see below) imply a genetic relationship between the different wehrlite bodies and suggest a common evolution.

[28] This correlation is also shown in the $\mathrm{TiO}_{2}$ in spinel versus $\mathrm{Mg} \#$ in olivine diagram in Figure 4 where most data points, especially those of the upper section, plot far away from Oman mantle harzburgites or from a mantle wehrlite from the EPR, suggesting that models based on a direct mantle derivation of the whole wehrlite suite [Benn et al., 1988; Jousselin and Nicolas, 2000] are probably not important here. On the other hand, it is known that olivines and spinels in mantle peridotites that have suffered significant impregnation by MORB-type melts would be lower in forsterite content and higher in $\mathrm{TiO}_{2}$, respectively, because of interaction with the impregnating melt. Thus, Figure 4 supports the option that those wehrlite with the very depleted clinopyroxene from the lowest part of the profile could be influenced by processes of mantle impregnation, which is also 

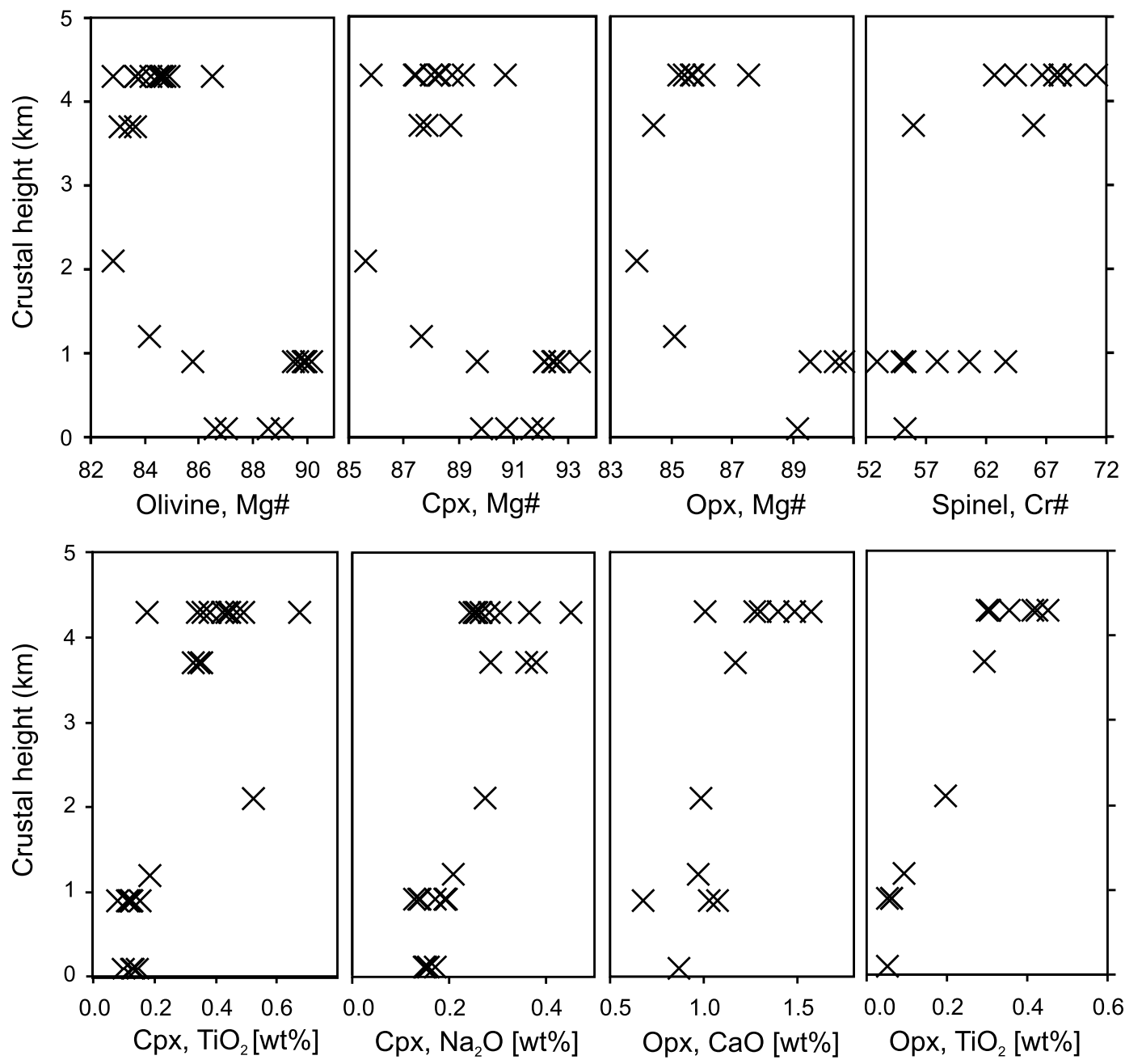

Figure 3. Variation of major and minor components of wehrlite minerals with lithostratigraphical height (km above Moho). Shown are the compositions from olivine, clinopyroxene, orthopyroxene, and spinel of massive wehrlites from six intrusions of different crustal level within the Wadi Haymiliyah section. Locations and crustal heights are given in Table A1.

supported by the trace element composition of the clinopyroxene (see section 6.2).

\subsection{Trace Element Compositions of Clinopyroxenes}

[29] Trace element concentrations were obtained by SIMS for clinopyroxene of 4 massive wehrlites from the Wadi Haymiliyah of different crustal level (Table 2). The chondrite-normalized REE and trace element patterns for clinopyroxenes of the investigated wehrlites show more or less identical trends with increasing concentrations with crustal height (Figures 5a and 5b). This clearly supports the result from the microprobe phase analysis that the different wehrlite bodies are genetically closely related showing a marked evolution trend from the bottom to the top of the plutonic crust of the Wadi Haymiliyah profile.

[30] Their chondrite-normalized REE patterns cover the range spanned by 25 gabbroic and wehrlitic samples from the crust-mantle transition zone (MTZ) of the southern Oman ophiolite block investigated by Koga et al. [2001] and which were interpreted as cumulates from typical MORB magma. In Figure 5a we present the calculated liquid equilibrium compositions using clinopyroxene/ melt partition coefficients of Hart and Dunn [1993] and compared them with Oman extrusive rocks of V1 type (similar to present-day MORB; see section 2.1) and V2 type (interpreted to be the result from fluid-enhanced melting of previously depleted mantle). Those equilibrium melts related 


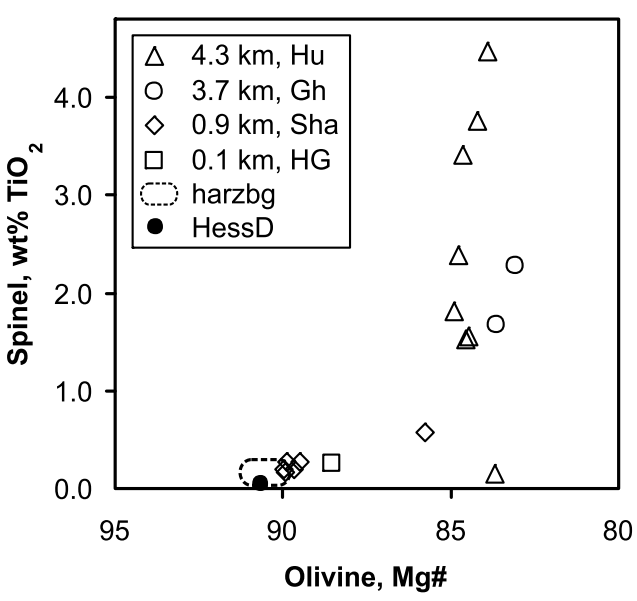

Figure 4. $\mathrm{TiO}_{2}$ in spinel versus magnesium number of olivine in massive wehrlites from the Wadi Haymiliyah section of different crustal level $(\mathrm{km}$ above the Moho; location code as in Figure 1). Shown is also the field for typical Oman harzburgites (harzbg) from the mantle [Kelemen et al., 1995], as well as one wehrlite from Hess Deep at EPR (HessD) interpreted as product of melt accumulation in the deep lithospheric mantle [Arai and Takemoto, 2007].

to clinopyroxenes from wehrlites of moderate to high crustal level, representing the majority of the wehrlite intrusive bodies of the Wadi Haymiliyah, fall into the range of normal MORB. This interpretation is in accord with the conclusion of Koga et al. [2001] based on their comprehensive data set for gabbroic and wehrlitic rocks from the MTZ.

[31] On the other hand, the two very primitive clinopyroxenes from wehrlites located near the
Moho (samples 4-73 and 4-82 in Figure 5a) are too depleted in REE compositions, (especially in HREE) for normal MORB origin. The corresponding calculated liquid compositions fit better with the lavas of V2 type, thus implying an origin from fluid-enhanced melting of previously depleted mantle. Since major and trace element phase chemistry suggests that the different wehrlite intrusions form a coherent suite, these results suggest a model that the crustal wehrlites of the Wadi Haymiliyah were formed by accumulation of early crystallizing phases in trace element depleted MORB with V2 affinity.

[32] Alternatively, the very depleted clinopyroxenes of the two MTZ wehrlites could be the result of equilibration of normal MORB melts with the depleted, shallow mantle section of the Oman ophiolite. Such an interpretation is presented by Koga et al. [2001] based on highly depleted clinopyroxenes with very similar REE patterns present in normal MORB-derived gabbroic rocks from the Oman MTZ. Moreover, some melt inclusions in olivines in MORBs from recent mid-ocean ridges are extremely depleted in REE ("ultradepleted melts," UDM) as reported by Sobolev and Shimizu [1993]. Such melts are interpreted to be re-equilibrated with a peridotitic residue at shallow pressure and have the potential to crystallize clinopyroxene similar in REE composition like those from the wehrlite samples 4-73 and 4-82. To conclude, the very limited trace element data for clinopyroxenes (only 4 samples) does not allow an unequivocal interpretation for the origin of the wehrlitic parental melts. However, since

Table 2. Average Trace Element Content in Clinopyroxenes Analyzed by SIMS ${ }^{\mathrm{a}}$

\begin{tabular}{|c|c|c|c|c|c|c|c|c|}
\hline & $04-35(\mathrm{n}=5)$ & $1 \sigma$ & $04-73(n=4)$ & $1 \sigma$ & $04-82(\mathrm{n}=4)$ & $1 \sigma$ & $04-105(\mathrm{n}=2)$ & $1 \sigma$ \\
\hline $\mathrm{La}$ & 0.19 & 0.04 & 0.04 & 0.01 & 0.05 & 0.00 & 0.16 & 0.05 \\
\hline $\mathrm{Ce}$ & 0.81 & 0.24 & 0.19 & 0.03 & 0.25 & 0.04 & 0.75 & 0.09 \\
\hline $\mathrm{Sr}$ & 11.02 & 0.49 & 8.51 & 0.53 & 8.61 & 0.33 & 11.56 & 0.88 \\
\hline $\operatorname{Pr}$ & 0.19 & 0.03 & 0.04 & 0.00 & 0.07 & 0.01 & 0.19 & 0.01 \\
\hline $\mathrm{Nd}$ & 1.33 & 0.14 & 0.37 & 0.08 & 0.51 & 0.07 & 1.61 & 0.13 \\
\hline $\mathrm{Zr}$ & 4.65 & 0.94 & 0.91 & 0.13 & 1.43 & 0.16 & 5.62 & 0.10 \\
\hline $\mathrm{Sm}$ & 0.78 & 0.14 & 0.20 & 0.02 & 0.34 & 0.07 & 0.83 & 0.02 \\
\hline $\mathrm{Eu}$ & 0.34 & 0.05 & 0.09 & 0.02 & 0.15 & 0.04 & 0.38 & 0.01 \\
\hline $\mathrm{Gd}$ & 1.56 & 0.16 & 0.37 & 0.07 & 0.54 & 0.09 & 1.59 & 0.11 \\
\hline $\mathrm{Ti}$ & 1907 & 106 & 573 & 66 & 812 & 88 & 2341 & 7 \\
\hline Dy & 2.12 & 0.34 & 0.44 & 0.08 & 0.80 & 0.06 & 2.09 & 0.03 \\
\hline $\mathrm{Y}$ & 10.56 & 1.40 & 2.42 & 0.33 & 3.70 & 0.42 & 10.30 & 0.18 \\
\hline $\mathrm{Er}$ & 1.35 & 0.20 & 0.26 & 0.07 & 0.42 & 0.06 & 0.98 & 0.01 \\
\hline $\mathrm{Yb}$ & 1.13 & 0.17 & 0.26 & 0.05 & 0.34 & 0.06 & 0.79 & 0.02 \\
\hline V & 188.0 & 13.1 & 122.6 & 25.5 & 168.0 & 17.5 & 252.7 & 2.8 \\
\hline $\mathrm{Cr}$ & 7370 & 357 & 5024 & 401 & 3469 & 205 & 6252 & 19 \\
\hline
\end{tabular}

\footnotetext{
${ }^{a}$ Trace element compositions are in ppm; " $n$ " indicates number of analyses.
} 


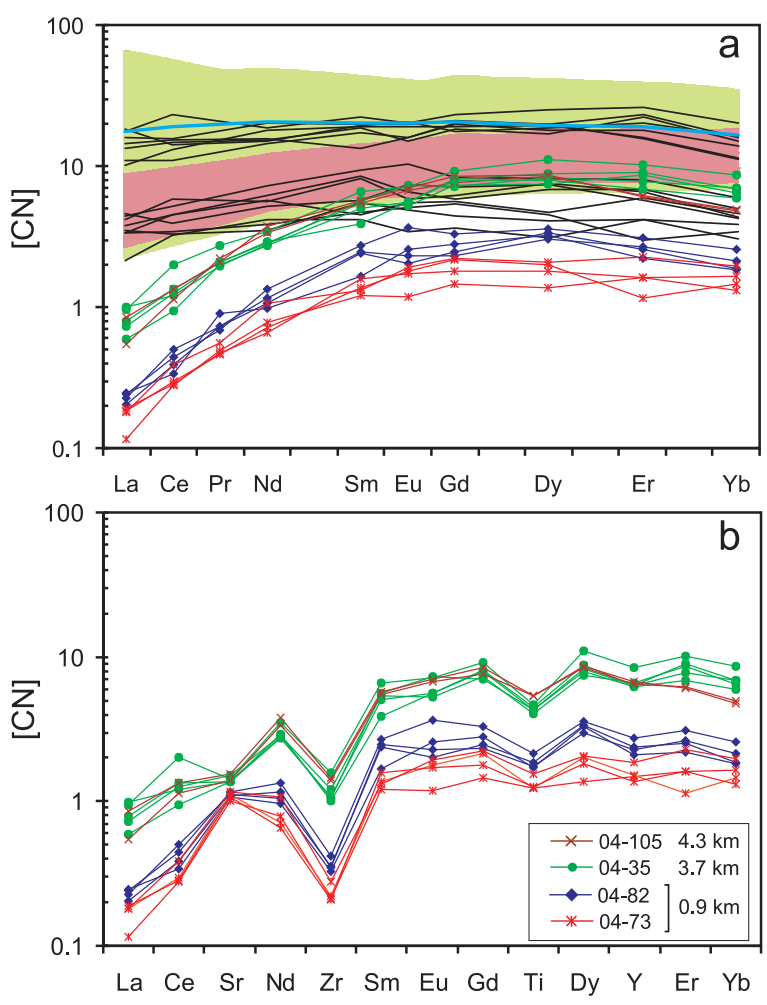

Figure 5. Trace element concentrations in clinopyroxenes of four massive wehrlites from the Wadi Haymiliyah of different crustal level $(\mathrm{km}$ above Moho as indicated in the legend of Figure $5 b$ ), normalized to the composition of CN [Anders and Grevesse, 1989]. (a) REE patterns and calculated liquid compositions in equilibrium with clinopyroxene (thin black lines). Included is an average primitive MORB (blue thick line) from Kelemen et al. [2004] and the range of REE compositions in Oman extrusive rocks of V1 type (green shaded field [from Pallister and Knight, 1981; Alabaster et al., 1982; Ernewein et al., 1988; Einaudi et al., 2003; Godard et al., 2003]) and of V2 type (red shaded field [from Godard et al., 2003]). (b) Trace element patterns.

large wehrlitic intrusive bodies like those from the Wadi Haymiliyah are not known up to now from the lower crust of modern ocean ridges, a normal ridge origin seems not very probable. Thus, a relation to the V2 magmatism is implied which is related to a fluid-enhanced melting of previously depleted mantle residual after V1 extraction, linked with a subduction process (see discussion on the different interpretation of "subduction" in section 2.1).

\subsection{Experimental Work}

[33] In order to evaluate the petrogenesis of the Oman crustal wehrlites we performed an experimental study under controlled $f \mathrm{O}_{2}$ and $a \mathrm{H}_{2} \mathrm{O}$ at a pressure of $200 \mathrm{MPa}$ (corresponding to a crustal depth of $\sim 6 \mathrm{~km}$ ) with the aim to constrain the physical conditions of wehrlitic magmas within the lower oceanic crust (for run conditions, see Table 3). Especially, we aimed to test the hypothesis, whether the crustal wehrlites from the Oman ophiolite are cumulates derived from wet MORBtype magmas, as suggested by previous experimental results of Feig et al. [2006] and by the findings of Koga et al. [2001] on natural wehrlites from the Samail massif. Since our experimental approach was to use natural wehrlite phases as starting material, it was necessary to add the lost equilibrium liquid, which was addressed by adding a synthesized glass with a calculated equilibrium composition (see section 3.4). The experimental strategy was, to bring the natural crystals together with the lost equilibrium melt, both under very low $a \mathrm{H}_{2} \mathrm{O}$ (nominally dry, "dry" in the following) and under water-saturated conditions ("wet" in the following), and to check the equilibrium behavior of the natural crystals (stability or dissolution). Of special interest was to elaborate those physical conditions, where the "wehrlite paragenesis" was stabilized (saturation of olivine and clinopyroxene, but not of plagioclase). We added only about 10 olivine and clinopyroxene crystals (grains size $<150 \mu \mathrm{m}$ ), leading to a compositional change of the system of less than $1 \%$. Analyses of the starting materials are listed in Table 4 . The chosen experimental system is a primitive tholeiitic composition, which is implied by trace element chemistry in clinopyroxene (see section 6.2).

[34] A synopsis of the experimental results including electron images and the derived phase diagram is shown in Figure 6. Calculated $\mathrm{Kd}_{\mathrm{Mg}-\mathrm{Fe}}$ for olivine/melt according to Toplis [2005] presented in Table 3 vary around 0.3 , suggesting that equilibrium compositions between the newly formed olivines and the melt was reached. The experiment at nominal dry conditions at $1200^{\circ} \mathrm{C}$ reveals the stability of plagioclase (newly formed crystals), while the doped clinopyroxene became unstable (decomposition by reaction with the melt). Below this temperature, plagioclase was always stable coexisting with clinopyroxene (Figures $6 \mathrm{a}$ and $6 \mathrm{~b}$ ). Thus, we were not able to reproduce the characteristic wehrlite paragenesis under dry conditions, implying that wehrlitic crystal mushes cannot be generated in dry, primitive tholeiitic systems at crustal pressure by simple accumulation of fractionating crystals. The phase assemblage of the experiment performed at $1060^{\circ} \mathrm{C}$ shown in Figure $6 \mathrm{c}$, however, demonstrates the stability of 
Table 3. Experimental Conditions

\begin{tabular}{|c|c|c|c|c|c|c|c|c|c|c|c|}
\hline Run & $\begin{array}{l}\text { Pressure } \\
\quad \text { (bar) }\end{array}$ & $\begin{array}{c}\text { Temperature } \\
\left({ }^{\circ} \mathrm{C}\right)\end{array}$ & $\begin{array}{l}\text { Duration } \\
\text { (h) }\end{array}$ & $\begin{array}{c}\mathrm{H}_{2} \mathrm{O} \text { in } \\
\mathrm{Melt}^{\mathrm{a}} \\
\left(\mathrm{wt}^{0} \%\right)\end{array}$ & $a \mathrm{H}_{2} \mathrm{O}^{\mathrm{b}}$ & $\begin{array}{l}p \mathrm{H}_{2} \\
\text { (bar) }\end{array}$ & $\begin{array}{l}\log f \mathrm{O}_{2} \text { at } \\
a \mathrm{H}_{2} \mathrm{O}=1\end{array}$ & $\begin{array}{l}\log f \mathrm{O}_{2} \\
\text { at run } \\
\text { cond. }^{\mathrm{c}}\end{array}$ & $\Delta \mathrm{QFM}^{\mathrm{d}}$ & $\begin{array}{c}\mathrm{Kd}_{\mathrm{Mg}-\mathrm{Fe}} \\
\text { Olivine/Melt }\end{array}$ & $\begin{array}{c}\text { Phase } \\
\text { Assemblage }\end{array}$ \\
\hline 1 & 2003 & 1160 & 2.5 & 1.3 & 0.17 & 1.94 & -6.43 & -7.95 & 0.65 & 0.293 & ol-cpx-pla-gl \\
\hline 2 & 2007 & 1200 & 1.5 & 0.4 & 0.02 & 2.07 & -5.97 & -9.44 & -1.31 & 0.293 & ol-pla-gl \\
\hline 3 & 2016 & 1180 & 2 & 1.6 & 0.23 & 2.30 & -6.31 & -7.58 & 0.78 & 0.294 & ol-cpx-pla-gl \\
\hline 4 & 1993 & 1060 & 5 & 5.6 & 1.00 & 1.91 & -7.84 & -7.84 & 2.06 & 0.277 & ol-cpx-gl \\
\hline 5 & 2050 & 1080 & 5 & 5.4 & 1.00 & 1.35 & -7.22 & -7.22 & 2.40 & 0.281 & ol-gl \\
\hline 6 & 2040 & 1040 & 5 & 6.0 & 1.00 & 2.23 & -8.27 & -8.27 & 1.91 & 0.274 & ol-cpx-pla-gl \\
\hline
\end{tabular}

\footnotetext{
${ }^{\mathrm{a}}$ Water content estimated by electron microprobe ("by-difference method").

${ }^{\mathrm{b}}$ The $a \mathrm{H}_{2} \mathrm{O}$ calculated after Burnham [1979].

${ }^{\mathrm{c}}$ The $\log \mathrm{fO}_{2}$ was calculated following Berndt et al. [2005].

d The log units of $f_{2}$ relative to the quartz-fayalite-magnetite oxygen buffer.

${ }^{\mathrm{e}}$ Calculated after Toplis [2005] with $\mathrm{Fe}^{2+} / \mathrm{Fe}^{3+}$ in the melt calculated according to Kress and Carmichael [1991]. Abbreviations: cpx, clinopyroxene; gl, glass; ol, olivine; pla, plagioclase.
}

clinopyroxene/olivine without plagioclase under conditions of water saturation which corresponds to a water content in the melt of $\sim 5 \mathrm{wt} \%$. This is in accord with water solubilities for MORB-type melts from the literature [e.g., Berndt et al., 2002]. A potential fractionation of this assemblage would lead to the formation of cumulate wehrlites. At a lower temperature of $1040^{\circ} \mathrm{C}$, finally, plagioclase becomes saturated (Figure 6d).

\subsection{Sr Isotopes}

[35] For evaluating the source of the fluids responsible for the magmatic amphibole formation we analyzed $\mathrm{Sr}$ isotopes from separates of poikilitic amphibole. For this, only those rocks from the locality Huwayl were suitable, showing enough amphibole for mineral separation. The measured ${ }^{87} \mathrm{Sr} /{ }^{86} \mathrm{Sr}$ ratios for the amphiboles vary between 0.70311 and 0.70564 (Table 5), thus exceeding significantly the values for fresh MORB with ${ }^{87} \mathrm{Sr} /{ }^{86} \mathrm{Sr}$ ratios typically lying between 0.70230 and 0.70290 [Hart et al., 1974]. The high ${ }^{87} \mathrm{Sr} /{ }^{86} \mathrm{Sr}$ ratios of samples 04-107 LN 1st and 04-107 LN 2nd (liquids extracted after the leaching experiment) show that relatively radiogenic $\mathrm{Sr}$ was removed from this particular amphibole separate during leaching indicating that low-T alteration obviously does play a role. However, the absolute Sr content of these leachates is low compared to that of the solid residue (Table 5). When extrapolating the results of the leaching experiment to the whole sample set, half of the samples fall within the MORB range. Since the elevation in ${ }^{87} \mathrm{Sr} /{ }^{86} \mathrm{Sr}$ relative to MORB for the other half of the samples is still of significance implying that the generally high ${ }^{87} \mathrm{Sr} /{ }^{86} \mathrm{Sr}$ ratios of the amphiboles are primary signatures and not related to secondary hydrothermal alteration. Implications of these results are discussed in section 7.4.

\section{Discussion}

\subsection{Crustal Wehrlites as Fractionation Products in Hydrous MORB}

[36] The experimental results in combination with results of the clinopyroxene trace element chemistry imply a model of crustal wehrlite petrogenesis, which is based on the accumulation of olivine and pyroxene in a primitive MORB magma, but under the conditions of high water activities $\left(a \mathrm{H}_{2} \mathrm{O}=1\right.$ in our experiments) where plagioclase saturation is not reached. The required high $a \mathrm{H}_{2} \mathrm{O}$ for stabilizing the wehrlite paragenesis in MORB magmas in the lower ocean crust can be easily achieved, since the water solubility in MORB melts at those shallow pressures prevailing in the ocean lower crust is low $(\sim 2.5 \mathrm{wt} \%$ at $100 \mathrm{MPa}, \sim 5 \mathrm{wt} \%$ at $200 \mathrm{MPa}$, $\sim 6 \mathrm{wt} \%$ at $300 \mathrm{MPa}$, according to Berndt et al. [2002]). For example, for a given pressure of $200 \mathrm{MPa}$ in the MTZ level (corresponding to $\sim 6 \mathrm{~km}$ crust), the solubility of water in a primitive MORB melt is $\sim 5 \mathrm{wt} \%$ [Berndt et al., 2002]. Thus, for stabilizing a MORB magma under high water activities consisting of $50 \%$ melt and $50 \%$ anhydrous minerals in the deep crust, with the potential to accumulate wehrlites, only $2.5 \mathrm{wt} \%$ water in the whole system is necessary (calculation for $a \mathrm{H}_{2} \mathrm{O}=1$ ). In case of a magma chamber residing at higher crustal level, for example at pressure of $100 \mathrm{MPa}$, only $\sim 1.25 \mathrm{wt} \%$ water is necessary for a 


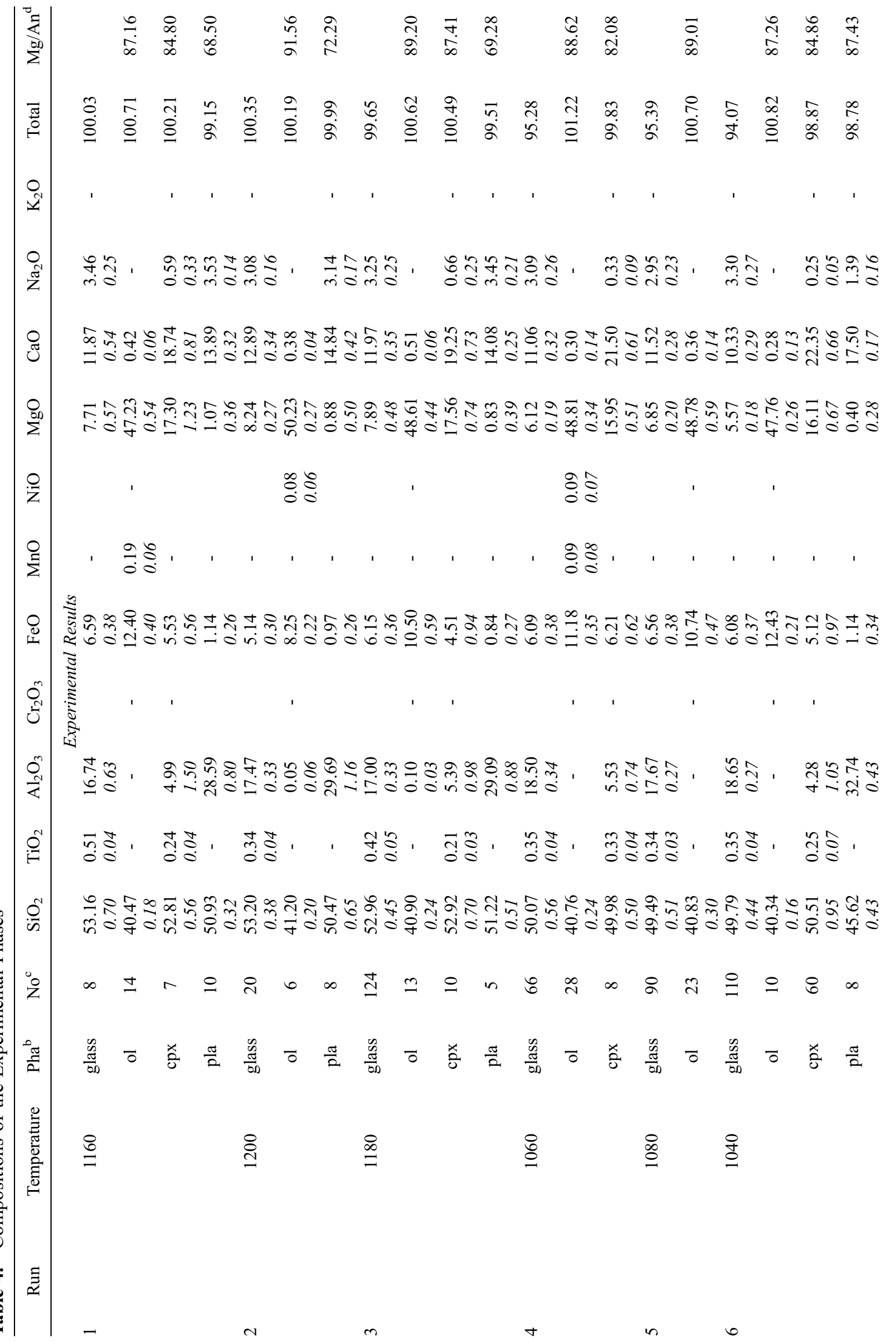


similar scenario with a melt fraction of $50 \%$ in the magma.

[37] QUILF two-pyroxene geothermometry [Andersen et al., 1993] reveal equilibrium temperatures ranging between 740 and $1040^{\circ} \mathrm{C}$ with large uncertainties ( 70 to $400^{\circ} \mathrm{C}$ ), reflecting that orthopyroxenes and clinopyroxenes in the wehrlites studied are obviously not in equilibrium. This fits with the petrographic observations that orthopyroxene crystallized later then clinopyroxene and with the generally lower $\mathrm{Mg \#}$ of orthopyroxene compared to the clinopyroxene. The highest equilibrium temperatures obtained by single clinopyroxene thermometry using QUILF are $\sim 1070^{\circ} \mathrm{C}$ which fits well with the experimental result suggesting temperatures for the stabilization of wet wehrlitic magma between 1040 and $1080^{\circ} \mathrm{C}$. Hornblendeplagioclase geothermometry [Holland and Blundy, 1994] reveals rather coherent equilibrium temperatures with an average value of $1039^{\circ} \mathrm{C}\left( \pm 23^{\circ} \mathrm{C}\right.$ for 8 pairs). This is concordant with the crystallization order observed in the wehrlites from the upper part of the crust, where true magmatic amphibole forms poikilitic networks enclosing olivine and pyroxene (Figure 2). Thus, experiments, geothermometry, and petrography reveal the following crystallization scenario: In a hydrous primitive MORB melt, cocrystallization of olivine and clinopyroxene occurred at temperatures between 1080 and $1040^{\circ} \mathrm{C}$, followed by the crystallization of orthopyroxene in some cases. Below $1040^{\circ} \mathrm{C}$, amphibole and plagioclase became saturated, which filled the interstices. After crystallization, cooling was rather efficient: neither exsolution phenomena in pyroxenes, nor significant zoning effects in the minerals were observed.

[38] The temperature interval for the intruding of wet, wehrlitic mush is fully in accord with the field observation that during wehrlite intrusion the surrounding layered gabbro was not a rigid solid mass. At a given temperatures of $1060^{\circ} \mathrm{C}$ (at $\left.200 \mathrm{MPa}\right)$, a corresponding primitive MORB system under dry condition would be slightly above the solidus [Feig et al., 2006], with the property of a crystal mush containing a few percent of melt, preventing plastic deformation of the minerals in the intruded gabbro, a feature which was not observed. This temperature interval is also in accord with the observation that the wehrlites intruded into the gabbros without any sign of contact metamorphism. Such effects should be expected if the intruding magma would be much hotter than the surrounding gabbros, making any model very improbable that the wehrlites could 

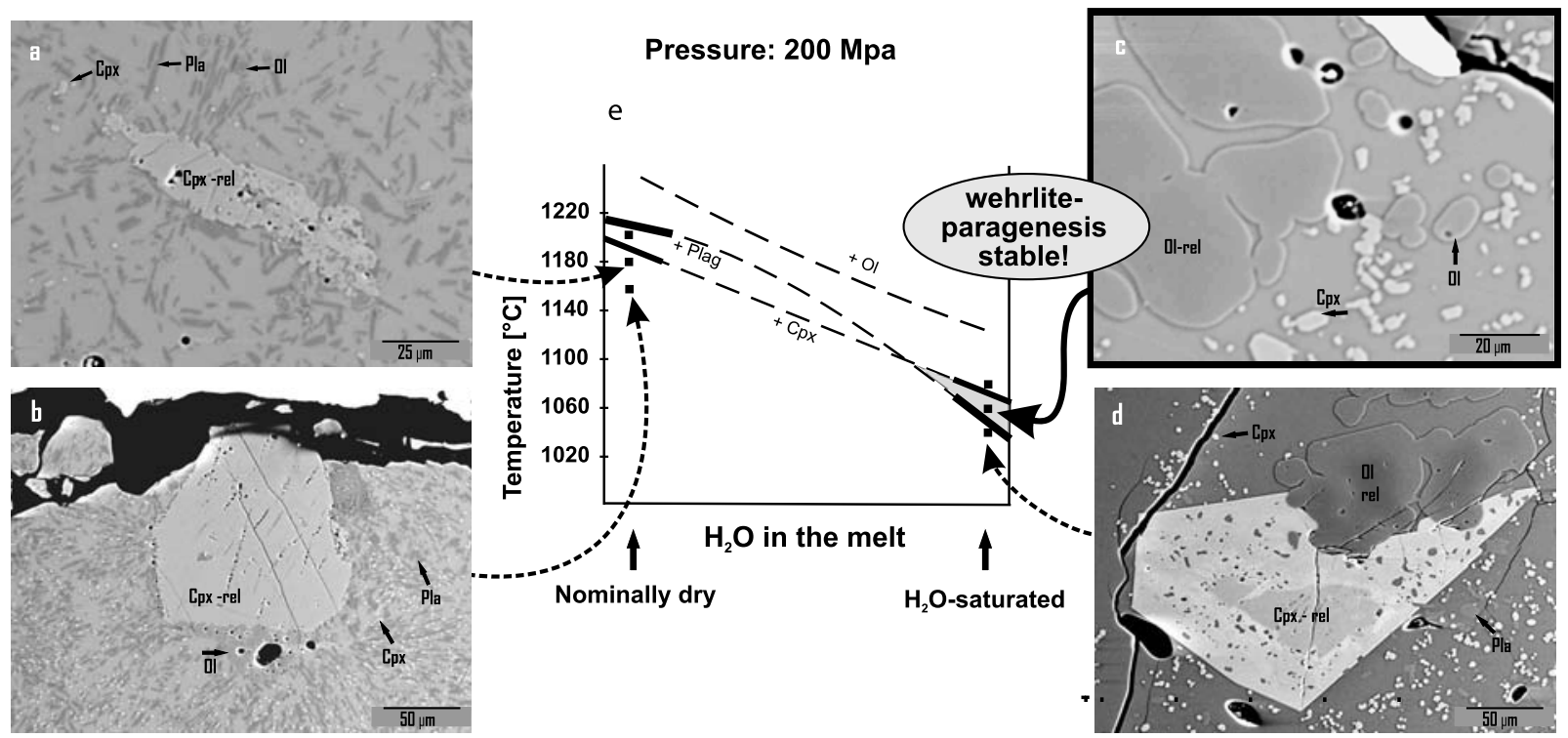

Figure 6. Experimental results: (a-d) BSE images and (e) phase diagram. BSE pictures of the experimental results performed at a pressure of $200 \mathrm{MPa}$ using a synthetic starting material doped with olivines and clinopyroxenes from natural wehrlites of the Wadi Haymiliyah. Figure $6 \mathrm{a}, 1180^{\circ} \mathrm{C}$, nominally dry; Figure $6 \mathrm{~b}, 1160^{\circ} \mathrm{C}$, nominally dry; Figure $6 \mathrm{c}, 1060^{\circ} \mathrm{C}$, water-saturated; Figure $6 \mathrm{~d}, 1040^{\circ} \mathrm{C}$, water-saturated. Abbreviations are as follows: Cpx, clinopyroxene; Ol, olivine; Pla, plagioclase; "rel" means relictic crystals from the starting material; the matrix is glass. The phase assemblage of the experiment performed at $1060^{\circ} \mathrm{C}$ shown in Figure $6 \mathrm{c}$ demonstrates the stability of clinopyroxene/olivine without plagioclase (the "wehrlite paragenesis") under "wet" conditions. A potential fractionation of this assemblage in a MORB magma would lead to the formation of cumulate wehrlites. In Figure 6d, large clinopyroxene and olivine grains from the starting crystals are visible, now with newly formed rims showing slightly different composition representing the equilibrium composition. Figure 6e shows the basic phase relations observed in our experiments in a primitive hydrous gabbroic system at $200 \mathrm{MPa}$ under oxidizing conditions (QFM+2 at water-saturated conditions) as a function of temperature and water content in the melt (extrapolated according to Feig et al. [2006]). Each black square represents one single experiment. The gray field marks the stability of the "wehrlite paragenesis," where olivine and clinopyroxene are stable but plagioclase is not.

represent (dry) melt-impregnated mantle peridotites. The temperatures of such crystal mushes would exceed $1200^{\circ} \mathrm{C}$ significantly, which should have initiated anatexis processes within the gabbros which were not observed.
[39] Concerning the composition of the newly formed experimental phases, two aspects are of importance as illustrated in Figure 7:

[40] 1. Mg\# of olivines of the wet system is as high, as in the dry system, although the crystalli-

Table 5. The ${ }^{87} \mathrm{Sr} /{ }^{86} \mathrm{Sr}$ Isotopic Compositions of Amphibole Separates From Wehrlites From the Locality SW Huwayl $^{\text {a }}$

\begin{tabular}{|c|c|c|c|c|c|c|}
\hline Sample & & $\begin{array}{c}\text { Sample } \\
\text { Weight (g) }\end{array}$ & $\begin{array}{c}\mathrm{Sr} \\
(\mathrm{ppm})\end{array}$ & $\begin{array}{c}{ }^{87} \mathrm{Sr} /{ }^{86} \mathrm{Sr} \\
(\mathrm{mbc})\end{array}$ & & Comments \\
\hline $07-36$ & & 0.01495 & 10.2 & 0.703436 & \pm 06 & \\
\hline $07-37$ & & 0.01870 & 11.8 & 0.704750 & \pm 04 & \\
\hline $07-45$ & & 0.01090 & 24.9 & 0.704471 & \pm 03 & \\
\hline $07-46$ & & 0.00512 & 20.1 & 0.705640 & \pm 07 & \\
\hline $04-104$ & & 0.01781 & 6.2 & 0.703482 & \pm 04 & \\
\hline $04-105$ & & 0.01268 & 12.9 & 0.703110 & \pm 03 & \\
\hline 04-106b & & 0.02220 & 8.2 & 0.703352 & \pm 04 & \\
\hline 04-107 & NL & 0.02351 & 7.3 & 0.704226 & \pm 02 & reference sample for leach experiment \\
\hline 04-107 & $\mathrm{LN}$ & 0.01903 & 6.9 & 0.703454 & \pm 03 & solid residue from leach \\
\hline 04-107 & LN1st & 0.01903 & 1.1 & 0.707149 & \pm 07 & 1st liquid from leach \\
\hline 04-107 & LN2nd & 0.01903 & 0.7 & 0.706641 & \pm 10 & 2nd liquid from leach \\
\hline
\end{tabular}

\footnotetext{
${ }^{\mathrm{a}}$ The $2 \mathrm{SE}$ uncertainties are reported to the last significant digit of the value. For details on the leaching experiment using sample 04-107, see
} section 3.3. 

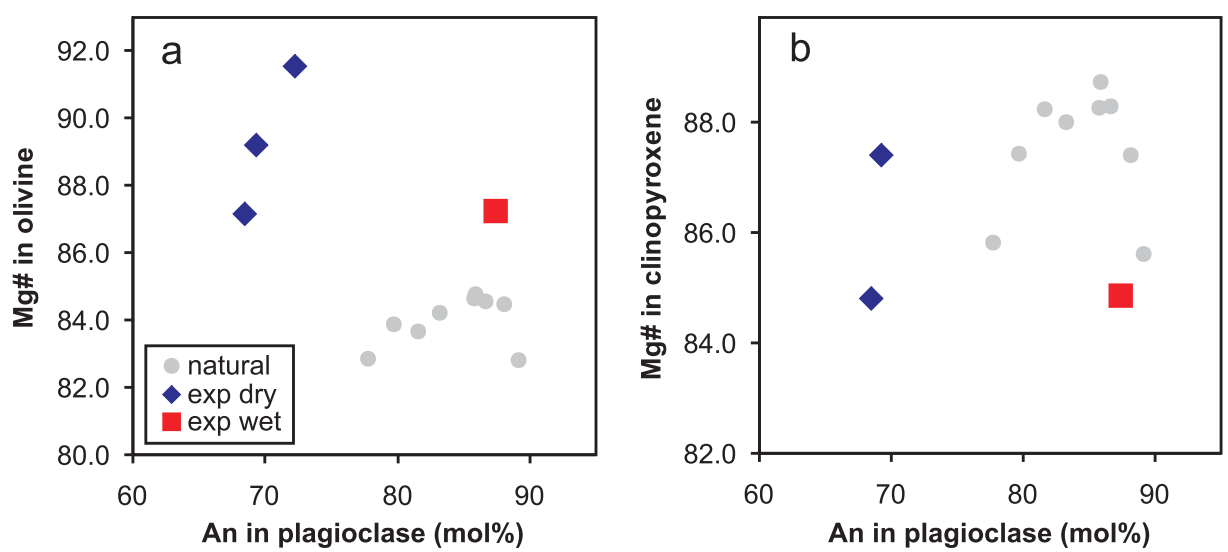

Figure 7. Comparison between plagioclase-bearing natural wehrlites and those runs containing plagioclase as experimental phase for dry (exp dry) and wet (exp wet) conditions. (a) Mg\# in olivine versus An in plagioclase. (b) $\mathrm{Mg \#}$ in clinopyroxenes versus An in plagioclase.

zation temperatures are distinctly lower. For example, the $\mathrm{Mg} \#$ of an olivine in a run performed at $1060^{\circ} \mathrm{C}$ in a wet system is 88.6 , while a practically identical value (89.2) was obtained for an olivine crystallized in a dry system at a temperature which was $120^{\circ} \mathrm{C}$ higher (Figure 7a). The reason for this is a combined effect of liquidus depression due to water [e.g., Danyushevsky, 2001; Almeev et al., 2007] and an increased $a \mathrm{H}_{2} \mathrm{O}$ which in turn oxidizes a system resulting in higher $\mathrm{Fe}^{3+} / \mathrm{Fe}^{2+}$ in the melt, and therefore higher $\mathrm{Mg \#}$ in the corresponding mafic phases [e.g., Berndt et al., 2005; Botcharnikov et al., 2005; Feig et al., 2006].

[41] 2. As expected from many previous experimental studies, the An content of plagioclase in the wet system is drastically higher: The An content of plagioclases from the run where first plagioclase crystallized under wet condition at $1040^{\circ} \mathrm{C}$ is $87.4 \mathrm{~mol} \%$, while the An content of the corresponding plagioclase under dry condition at $1200^{\circ} \mathrm{C}$ is $72.3 \mathrm{~mol} \%$ (Figure 7 and Table 4). This has consequences for those diagrams where the relation between $\mathrm{Mg} \#$ of clinopyroxene and $\mathrm{An}$ of plagioclase in oceanic plutonic suites is used to constrain geotectonic environments (e.g., midocean ridge, back-arc, or fore-arc region [Kvassnes et al., 2004; Feig et al., 2006; Yamasaki et al., 2006]). Here, we show that water alone has the potential to influence such differentiation trends significantly, independently of any geotectonic setting. Moreover, the comparison of the experimental results with the natural wehrlites reveals that only the plagioclase crystallized under wet conditions shows the high An contents recorded in the interstitial plagioclases of the natural wehrlites of the
Wadi Haymiliyah (Figure 7), providing another argument for wet wehrlite formation.

\subsection{Magma Evolution}

[42] As demonstrated above, the wehrlites in the Wadi Haymiliyah show an evolution trend with crustal height, evident by the observed characteristic trends in mineral compositions (Figure 3). The high-level wehrlitic bodies from Gharwah and Huwayl crystallized clearly at lower temperatures indicated by the presence of late amphibole and plagioclase, thus probably representing a higher stage of differentiation compared to the wehrlites from the lower crust. In principle, the following fractional crystallization scenario could be possible: Early olivine and clinopyroxene may accumulate in a wet tholeiitic magma near the MTZ, forming a primitive wehrlitic mush, which may intrude into the surrounding layered gabbros and freeze there, representing the low-level wehrlites. The remaining melt, now more differentiated, may rise into the upper crust and freeze there, forming the high-level wehrlites. Such a process may also account for the enrichment of REEs recorded in the clinopyroxene (Figure 5a). However, the amount of the observed REE enrichment (Figure 5a) requires $\sim 90 \%$ fractional crystallization mainly of olivine in a wet primitive MORB-type system. This implies a scenario that one of the largest wehrlite body near Huwayl would have been formed after $\sim 90 \%$ of olivine crystallization. As consequence, one should expect huge amount of cumulate dunite masses in the lower crust which do not exist. Thus, the pure fractionation model seems not very probable explaining the evolution with crustal height of the Wadi Haymiliyah wehrlites. 
[43] In addition to fractional crystallization, assimilation/contamination processes can also be considered as possible mechanism for the observed mineral evolution trends with height. This scenario is based on a model that individual wet probably SSZ-related wehrlitic mushes enter the crust (see section 7.4.1). While the lower wehrlite bodies intruded into cumulate gabbros with primitive geochemical character (layered gabbros, often intercalated with laminated, orthopyroxene-bearing gabbros; for compositions, see Yamasaki et al. [2006]), the two uppermost wehrlite bodies intruded into a sequence dominated by more evolved high-level, isotropic gabbros of variegated character which include also diorites, trondjhemites, and amphibole-bearing gabbros. Thus, the high-level wehrlitic magmas has the potential to interact with more evolved wall rock lithologies increasing the probability to evolve by assimilation of more $\mathrm{SiO}_{2}$-rich wall rocks. Because of the lower melting temperatures, fragments of evolved rocks incorporated into wet primitive wehrlitic magmas have the potential to get completely dissolved, thereby increasing the amount of $\mathrm{SiO}_{2}$ and of incompatible elements in the melt, while primitive cumulate gabbros with much higher melting temperatures may be preserved as refractory xenoliths. Such meter-sized xenoliths of former cumulate gabbro are still visible in the large high-level wehrlite body near Huwayl. These blocks preserved their primary layered structure, which is now of diffuse, blurred character, but show evidence that hydrous partial melting proceeded, probably as a result of interaction with the wehrlitic magma (see section 7.3).

[44] A third potential mechanism responsible for the observed mineral evolution trends with crustal height is the contamination of the wehrlitic mushes by trace element-enriched, seawater-derived fluids. As outlined in section 7.4.2, there is a possibility that seawater-derived fluids may have played a role in very late magmatic stage at the Oman paleoridge. Depending on the model, water-rich fluids of seawater origin may be derived from the top or the bottom into the magmatic cycle with the potential to trigger magmatic processes, i.e., by lowering the solidus and initiating partial melting of previously formed rocks, or by the addition of water-rich fluids to existing magmatic systems. In principle, only some weight percent of seawater are necessary for triggering such a process (see above). However, pure seawater cannot significantly change the trace element budget of a magmatic system. However, the newly formed, highly reactive wet magmas may subsequently undergo assimilation and contamination processes as outlined above, with a high potential to modify the trace element compositions significantly. In such a scenario, especially the assimilation of evolved material from the higher crustal level would be very efficient to shift the trace element concentrations of the wehrlites upsection to higher values (similar as described in the previous paragraph).

[45] The development of more sophisticated magma evolution models based on the clinopyroxene trace element chemistry is hampered because of the fact that only four clinopyroxenes were analyzed with SIMS, and from those, two show practically identical patterns.

\subsection{Effects of Hydrous Partial Melting in the Adjacent Gabbros}

[46] Both in the intruded gabbros near the contact to the wehrlites as well as in enclaves from layered gabbro within the wehrlites, we found those typical microstructures suggesting that hydrous partial melting reactions proceeded [Koepke et al., 2004, 2005a]. The characteristic paragenesis consists of interstitial pyroxene and pargasitic amphibole in intimate contact with neoblastic plagioclase strongly enriched in anorthite (Figure 8). The composition of the new An-rich plagioclase is strongly impoverished in incompatible trace element excluding a model that these An-rich zones were precipitated by late, hydrous evolved melts. This is in agreement with recent water-saturated melting experiments on a variety of natural gabbros [Koepke et al., 2004] between 900 and $1000^{\circ} \mathrm{C}$. As in typical gabbros from recent oceans [Koepke et al., 2005a, 2005b], the observed microstructures imply the propagation of water-rich fluids on grain boundaries inducing partial melting. The intimate association to the wehrlite intrusion suggests a model that the fluid phase triggering partial melting was exsolved during the solidification of the wet wehrlitic magma. It should be noted that the observed mineral phases are all of residual character, left after the partial melting event, while the corresponding felsic melts (so-called oceanic plagiogranites [e.g., Coleman and Donato, 1979; Koepke et al., 2007]) were not observed as products frozen in situ. It is very likely that the generated felsic melts segregated/migrated away, and solidified in fractures or cracks within the gabbroic host rocks in a slightly cooler, eventually brittle regime. 

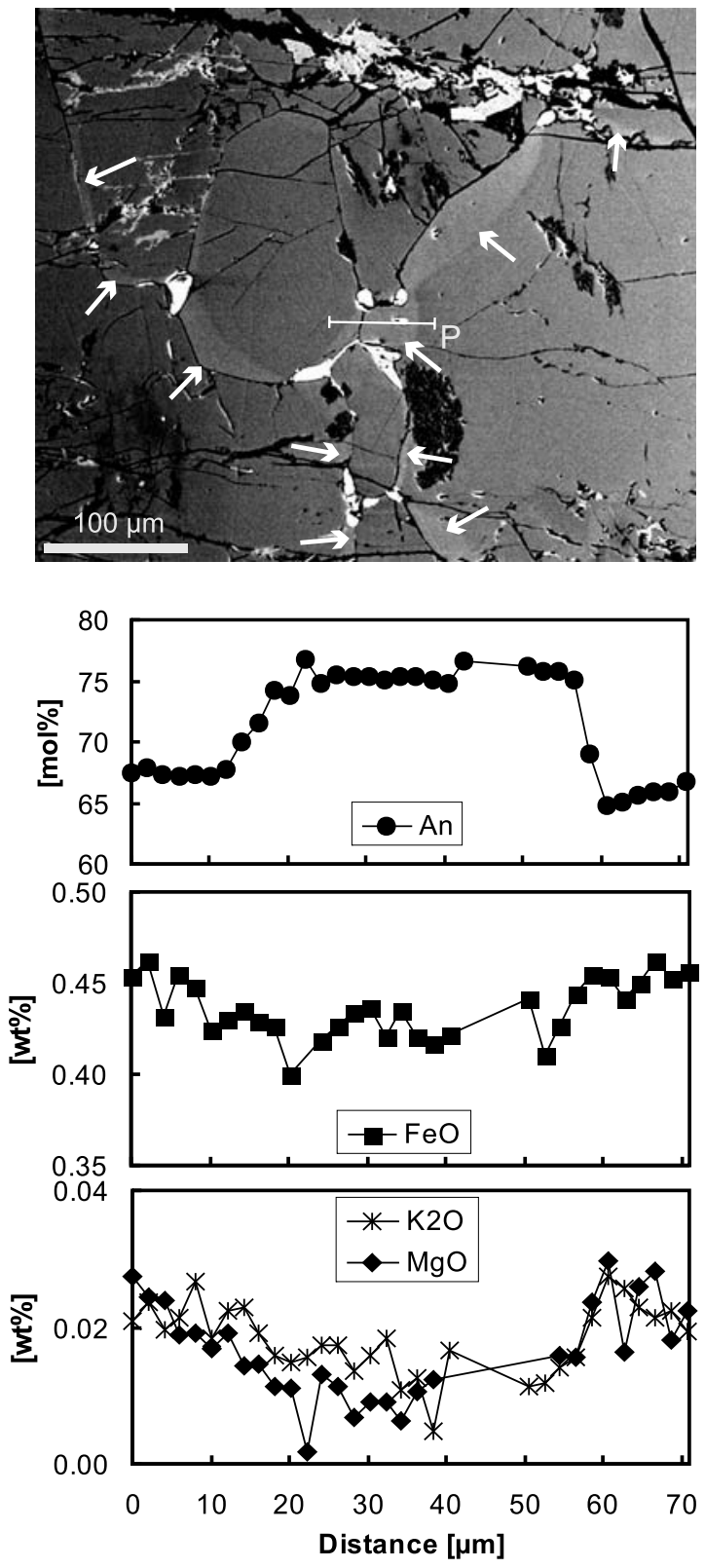

Figure 8. BSE picture and microprobe profiles from plagioclase grains of a gabbro directly from the intrusive contact wehrlite/gabbro. Along the grain boundaries, the plagioclases show zones strongly enriched in An (white arrows) coexisting with pargasitic amphibole (white minerals on grain boundaries), suggesting that partial melting proceeded, triggered by hydrous fluids which percolated on grain boundaries (see text for details). In addition, the sample shows cracks and signs of secondary alteration. The line indicates the location of a microprobe profile for $\mathrm{An}, \mathrm{FeO}, \mathrm{K}_{2} \mathrm{O}$, and $\mathrm{MgO}$ through a zone of An-enriched plagioclase. Note that some points of the profile were excluded because of the presence of a pargasite inclusion. Sample 07-30 from Huwayl Oasis.
Such felsic intrusives are very common in the investigated working area (e.g., plagiogranitic dikes and plugs, gabbroic breccias with plagiogranitic matrix [e.g., Juteau et al., 1988a; Reuber et al., 1991]).

\subsection{Nature of the Involved Water}

\subsubsection{Magmatic Source?}

[47] The wehrlites in the Wadi Haymiliyah belong to the group of so-called "late stage intrusives" [e.g., Lippard et al., 1986], together with late gabbronorites ("laminated gabbro" in Figure 1) and oceanic plagiogranites [Juteau et al., 1988a; Reuber et al., 1991]. Recent experimental phase equilibria studies in hydrous tholeiitic systems show that the formation of all these lithologies is supported by the presence of water in MORB systems [Koepke et al., 2004; Feig et al., 2006]. Thus it is indicated, that during a late stage of ocean crust formation at the Oman paleoridge, water-rich fluids became very important.

[48] In principle, this water could be simply primary magmatic. However, primary MORB melts are very poor in water [e.g., Sobolev and Chaussidon, 1996; Dixon et al., 2002], and a significant amount of a water-rich fluid phase could only be generated by extreme differentiation (exsolving of a fluid phase by oversaturation in a plagiogranitic melt). To reach such a differentiation stage, a MORB system must cool down below $1000^{\circ} \mathrm{C}$ [e.g., Berndt et al., 2005] to a state, where the temperatures are too low for the formation of crustal wehrlites.

[49] More evidence against primary MORB water is provided by $\mathrm{Sr}$ isotopes. As shown in Figure 9, ${ }^{87} \mathrm{Sr} /{ }^{86} \mathrm{Sr}$ ratios of amphiboles from the crustal wehrlites located at Huwayl (Table 5) fall between values for fresh MORB (0.7023-0.7029 according to Hart et al. [1974]) or primary magmatic rocks in this area [McCulloch et al., 1981; Kawahata et al., 2001] and Cretaceous seawater $(0.7073$ at $90 \mathrm{Ma}$ [after Burke et al., 1982]). When extrapolating the results of the leaching experiment to the whole sample set, half of the samples fall within the MORB range. The other half, however, is indicating elevated ${ }^{87} \mathrm{Sr} /{ }^{86} \mathrm{Sr}$ ratios relative to MORB, implying that the generally high ${ }^{87} \mathrm{Sr} /{ }^{86} \mathrm{Sr}$ ratios of the amphiboles are not related to secondary hydrothermal alteration, excluding a model, in which the crustal wehrlites are generated because of the presence of primary water developed during pure mid-ocean ridge magmatic processes. 


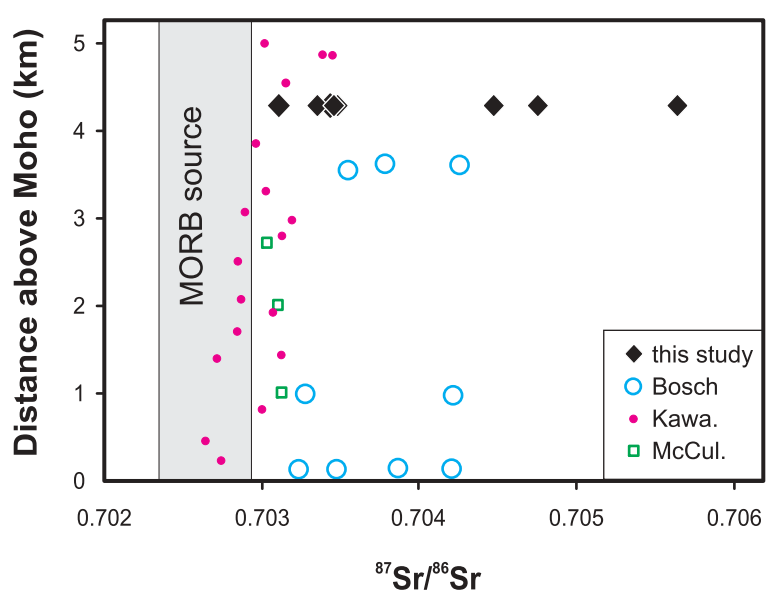

Figure 9. The ${ }^{87} \mathrm{Sr} /{ }^{86} \mathrm{Sr}$ isotopic composition for separates of poikilitic amphiboles from wehrlites from the Wadi Haymiliyah (locality Huwayl). Shown are also ${ }^{87} \mathrm{Sr} /{ }^{86} \mathrm{Sr}$ isotopic ratios for whole rocks from those gabbros from McCulloch et al. [1981] and Kawahata et al. [2001] representing primary signals, where the influence of secondary hydrothermal alteration is negligible, and for separated minerals from Bosch et al. [2004] as function of crustal height. From the data set of Bosch et al. [2004] only $\mathrm{Sr}$ isotopic rations from separates of those minerals formed magmatically by interaction with seawater are shown (clinopyroxene, pargasite, plagioclase) and analyses of secondary phases formed at greenschist-facies conditions as well as whole rock analyses are excluded. The field for MORB is from Hart et al. [1974]. The ratio for Cretaceous seawater is 0.7073 [Burke et al., 1982].

[50] In principle, the enhanced ${ }^{87} \mathrm{Sr} /{ }^{86} \mathrm{Sr}$ ratios could be attributed to seawater-derived fluids added during the magmatic cycle, as discussed in section 7.4.2. Alternatively, the observed shift in ${ }^{87} \mathrm{Sr} /{ }^{86} \mathrm{Sr}$ ratios toward more radiogenic values than is usual for MORB could be a consequence of interaction with fluids originated from deep subduction processes in an SSZ environment [e.g., Miyashiro, 1974; Pearce et al., 1984; Yamasaki et al., 2006].

[51] According to the SSZ model for the Oman ophiolite where a steeply dipping detachment is involved (see review by Warren et al. [2007]), water can only be transported in the form of hydrous melts, which are generated in a relatively deep mantle region (e.g., at pressures $>1 \mathrm{GPa}$ ). These wet basaltic melts may rise and segregate, until they finally get stuck as crystal mushes in the previously formed crust. However, such melts should show the trace element signatures of typical basalts, which is not indicated by the trace element signatures of the clinopyroxenes of the wehrlites and the calculated equilibrium melts (Figure 5a).

[52] Alternatively, wehrlitic mushes could have been formed by accumulation in wet SSZ magmas at moderate depth. This is indicated from juvenile arcs where fractionation in primary arc basalts occurred at considerable depth (pressures between 800 and $600 \mathrm{MPa}$ ) producing olivine- and clinopyroxene-bearing ultramafic cumulates, for example manifested in the $85 \mathrm{Ma}$ years old Chilas Complex in Kohistan, NW Pakistan [Jagoutz et al., 2007]. One could argue whether the wehrlitic rocks of Wadi Haymiliyah represent such frozen mushes, generated at depth and transported as crystal mush into the shallow crustal level of the spreading center. However, the minor elements in clinopyroxenes of the corresponding cumulates from the Chilas Complex reveal a characteristic high pressure trend, which is not observed for the clinopyroxenes of the crustal wehrlites from the Wadi Haymiliyah (Figure 10). Moreover in such deeply formed cumulates, orthopyroxene is a very dominant phase, which plays only a minor role in the wehrlites from the Wadi Haymiliyah. In addition, the patterns for the calculated equilibrium melts (Figure 5a) do not show a characteristic LIL element enrichment as it is to expect for typical arc basalts. To summarize, it is not very probable that

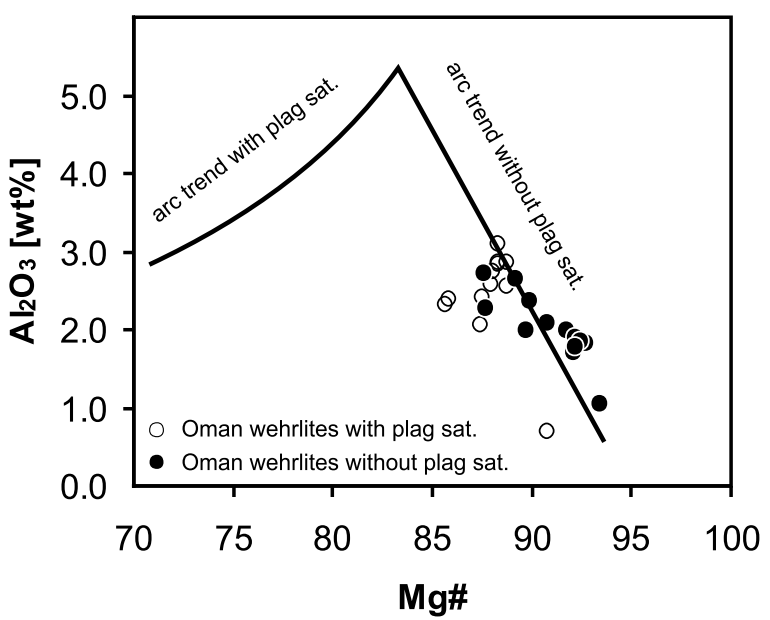

Figure 10. $\mathrm{Al}_{2} \mathrm{O}_{3}$ versus $\mathrm{Mg \#}$ of clinopyroxenes in massive wehrlites from the Wadi Haymiliyah with and without plagioclase saturation. Included is the differentiation trend for typical arc cumulates from the Chilas Complex, Kohistan, NW Pakistan, formed under elevated pressures $(600-700 \mathrm{MPa})$, which is characterized by an increasing $\mathrm{Al}_{2} \mathrm{O}_{3}$ content with decreasing $\mathrm{Mg \#}$ until plagioclase saturation is reached [Jagoutz et al., 2007]. 
the wehrlites from the Wadi Haymiliyah are related to deep, SSZ-related accumulation processes in wet tholeiitic magmas.

\subsubsection{Seawater Source?}

[53] As alternative water source, seawater can be considered. Here, different mechanisms are discussed how to incorporate water into the magmatic regime: (1) assimilation of previously altered oceanic crust, (2) hydrothermal circulation under very high temperatures, (3) fluid transportation during deep faulting due to ridge tectonics, and (4) fluid involvement by intraoceanic thrusting due to the beginning of obduction.

[54] 1. The addition of water by assimilation of previously altered oceanic crust [Gillis and Coogan, 2002; Koepke et al., 2008] seems not relevant for the genesis of the crustal wehrlites, since this type of assimilation is related to the up and down moving of the axial magma chamber, thus exclusively related to the uppermost part of the gabbro layer, while the Oman wehrlites are common also in the lower part of the plutonic crust.

[55] 2. On the basis of observations in the Oman ophiolite, a model on deep hydrothermal circulation at fast spreading ridges operating via a microcrack network under very high temperatures $\left(\sim 1000^{\circ} \mathrm{C}\right)$ was developed [e.g., Nicolas et al., 2003; Bosch et al., 2004]. As discharge system, a network of clinopyroxene, pargasite gabbroic dikes issued from the hydrous melting was identified. Crustal wehrlites were not explicitly reported as part of the discharge system. We believe that it is not very probable that the crustal wehrlites are the result of such a high temperatures alteration, for the following reasons: First, temperatures of $\sim 1000^{\circ} \mathrm{C}$ are too low for stabilizing wehrlitic crystal mushes. Second, since the crustal wehrlites are very common in the Oman crust (25\% of the crust according to Jousselin and Nicolas [2000]), wehrlites should be expected also in the plutonic crust of modern fast spreading ridges. However, up to now, true wehrlites were not sampled from such places where the deep crust is accessible by submersible (e.g., from the EPR: Hess Deep and Pito Deep; J. Karson, personal communication, 2008). Third, our experimental results show that very high melt fractions are necessary to stabilize those conditions where wehrlites can be formed by crystal accumulation. This means that the majority of the preexisting gabbro should be consumed by hydrous partial melting. This process would cause vast effects of migmatization in the gabbroic crust which must be visible in the field, which is not the case.

[56] 3. The eastern end of the Haylayn massif exposes a complex paleoridge structure interpreted as the tip of a northwestward propagating segment as pointed out by Juteau et al. [1988a] and Nicolas et al. [2000]. In such a peculiar situation, tectonic forces may establish the incorporation of seawater into the deep crust [Boudier et al., 2000] which may initiate hydrous magmatism, mainly expressed by the presence of orthopyroxene-rich gabbros. Details of the corresponding mechanisms, how seawater is added into the magmatic system are not known.

[57] 4. Another possible source for the incorporation of water-rich, seawater-derived fluid into the magmatic cycle has been proposed resulting from the early thrusting at the ridge axis along the flat lithosphere/asthenosphere boundary, where a hot mantle wedge overrode a zero age crust ("intraoceanic thrusting" or "shallow subduction" according to the MOR model presented in section 2.1 [Boudier et al., 1985; Hacker et al., 1996; Ishikawa et al., 2002; Boudier and Nicolas, 2007]). In such a scenario (Figure 11), considerable amounts of water are available because of the dehydration of sediments and altered crust at the top of the lower wedge. Moreover, since the magmatic activity in the upper wedge is in a final state or just ceased, temperatures in the lower crust of the upper wedge are assumed to be still high enough for the stabilization of late, hydrous wehrlitic crystal mushes. As outlined in section 7.1, the addition of only a few percent water to a dry, nearly solid rigid cumulate mush has the potential to shift solidus and liquidus of the system considerably, resulting in the formation of low-viscosity, mobile, and highly reactive wet magmas. These may subsequently undergo assimilation and contamination processes during ascent which may in turn modify the trace element compositions significantly. Such a scenario may account for the observation that the phases in the different wehrlite bodies investigated show enrichment in incompatible elements with crustal height.

\section{Conclusion}

[58] 1. The experiments in combination with the investigation on natural wehrlites from the Wadi Haymiliyah reveal the coherent result that the wehrlites represent frozen crystal mushes, derived from the accumulations of early olivine and clino- 


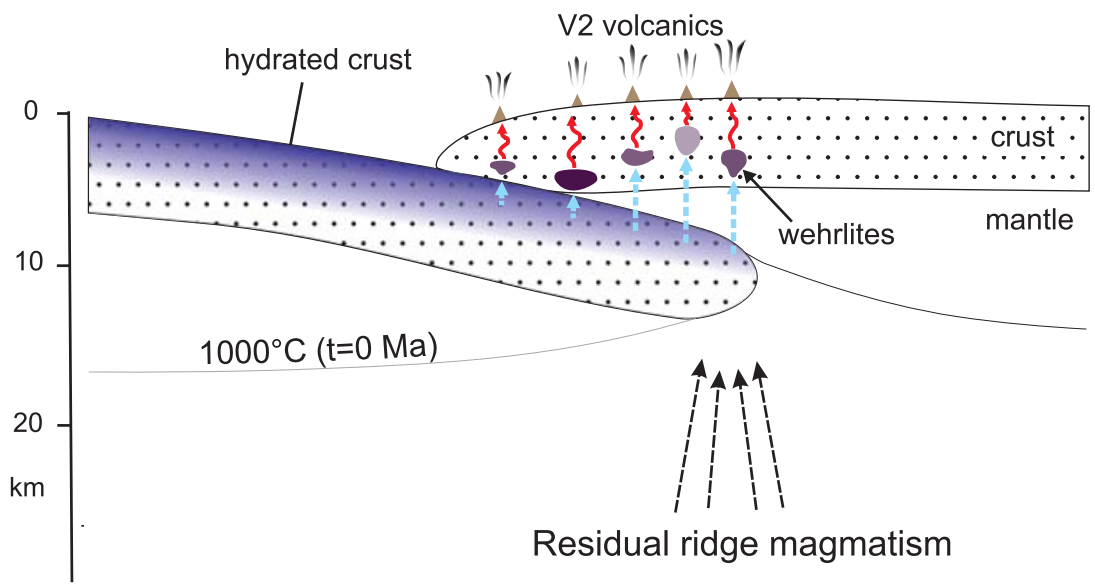

Figure 11. Cartoon illustrating a conceptual model on the petrogenesis of crustal wehrlites in an upper wedge above an initial, shallow subduction zone. Shown is the situation at $\sim 1$ Ma years after the beginning of the intraoceanic thrusting based on a tectonic model of Boudier et al. [1985] and Boudier and Nicolas [2007]. Water-rich fluids (light blue arrows), deliberated by dehydration of altered crust and sediments of the lower wedge, penetrate upward into the upper wedge, initiating a late, wet magmatic phase. Crystal accumulation in the wet MORB-type magmas leads to the intrusion of wehrlitic mushes, while the corresponding melts may escape upward, forming the V2 volcanics with "arc" affinity. The $1000^{\circ} \mathrm{C}$ isotherm is taken as the limit of the mechanical lithosphere, used as the detachment plane at the ridge according to Boudier and Nicolas [2007]. The horizontal distance is out of scale.

pyroxenes crystallized in hydrous MORB-type magmas.

[59] 2. The temperature to stabilize the wet wehrlitic crystal mushes is surprisingly low, between 1040 and $1080^{\circ} \mathrm{C}$. This is the reason for the absence of any significant contact-metamorphic phenomenon in the intruded gabbros. Hot and dry, probably mantle derived wehrlitic crystal mushes would have caused significant anatexis effects, which are not visible in the field.

[60] 3. The presence of water in the system has a strongly oxidizing effect. A rough estimation based on experimental data of Feig et al. [2006] reveals that a dry MORB melt with a $f \mathrm{O}_{2}$ of $\sim Q$ QFM will be shifted to highly oxidizing conditions of QFM +2 , just by increasing the water content from nominally dry to a value where water saturation is reached. The high oxidation state in wehrlitic magmas supports the stabilization of orthopyroxene (for details, see Feig et al. [2006]) which was observed as minor phase in many wehrlites investigated. That the prevailing redox conditions during magma evolution were highly oxidizing is also indicated by high amounts of $\mathrm{Fe}^{3+}$ in the analyzed spinels (based on stoichiometric calculation). Especially those spinels from wehrlites from the higher crustal level show stoichiometric $\mathrm{Fe}^{3+} /\left(\mathrm{Fe}^{3+}+\mathrm{Al}+\mathrm{Cr}\right)$ contents which are as high as those from experiments of Feig et al. [2006] performed in a primitive tholeiitic system at highest oxidation condition under water saturation.

[61] 4. Under wet conditions, a MORB magma has the potential to produce quite primitive early phases expressed by high $\mathrm{Mg \#}$ and An contents, in contrast to the dry system. Thus, water alone has the potential to influence differentiation trends based on the mineral compositions significantly, independently of any geotectonic setting.

[62] 5. The experiments revealed that water is a prerequisite for the formation of crustal wehrlites. Two scenarios for the wehrlite formation seem possible: contamination of primitive MORB by seawater during intraoceanic shearing within a shallow, initial subduction zone with subsequent assimilation (related to the MOR model in section 2.1), or, differentiation of a wet SSZ magma coupled with assimilation (related to the SSZ model in section 2.1). Minor element trends in clinopyroxenes (Figure 10) and the patterns for the calculated equilibrium melts (Figure 5a) support the former model.

[63] 6. Our results confirm a model that the typical late stage lithologies of the Oman ophiolite are generally related to a hydrous magmatism. The differentiation of wet MORB may lead to wehrlitic mushes which may freeze in the deep crust, while differentiated, evolved melts may escape upward, 


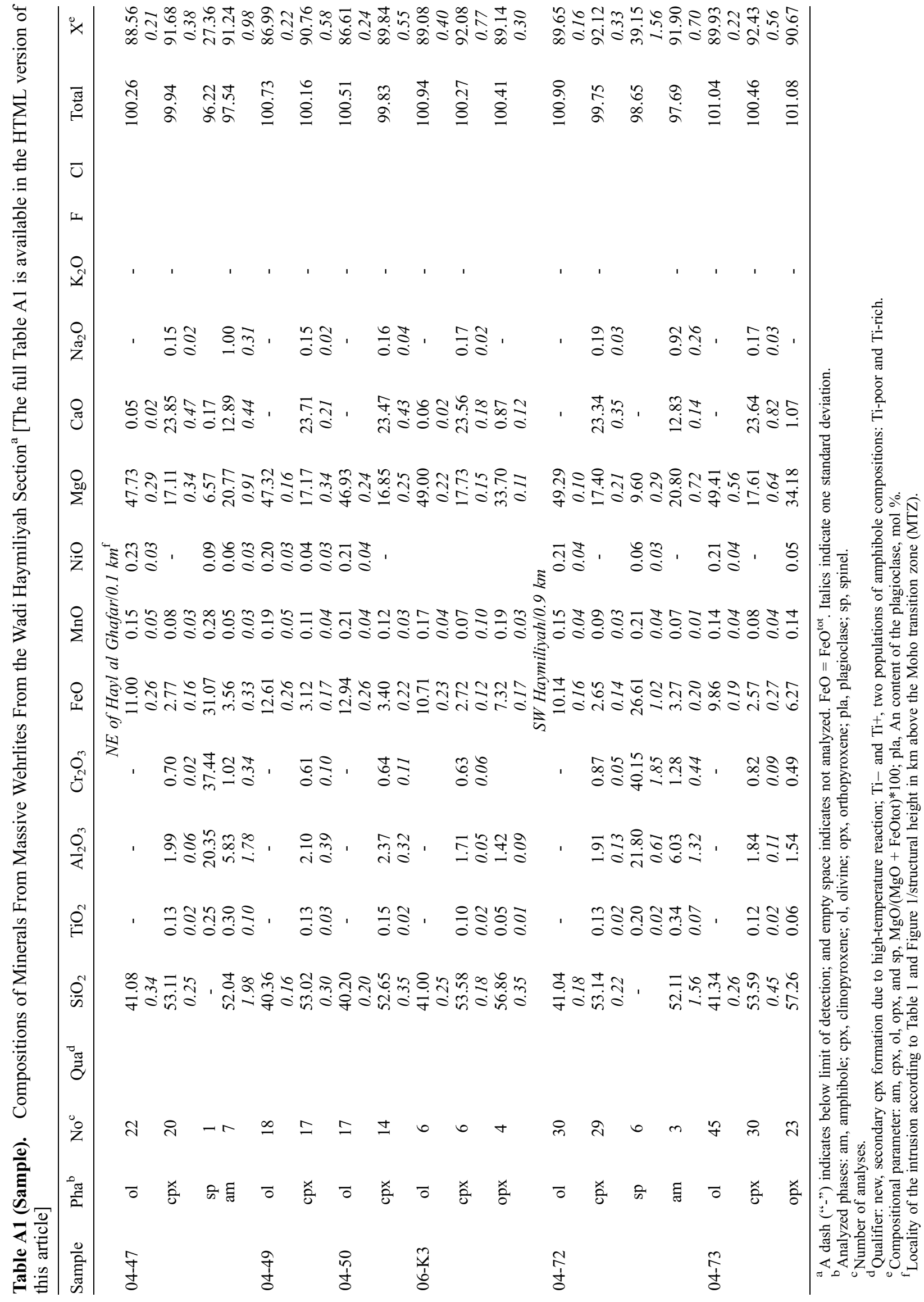


forming typical V2 volcanics. The close relation between the wehrlites and V2 volcanics was recently confirmed by trace element chemical investigations on clinopyroxenes in the Wadi Haymiliyah [Yamasaki et al., 2006] and also in the Fizh block [Yamazaki and Miyashita, 2008]. These authors concluded that the hydrous petrogenesis of the late stage lithologies is related to a setting above a subduction zone. The present study clearly indicates that water must be available for producing those rocks forming the late stage intrusives in the Oman ophiolite, but the presence of water does not necessarily mean that a "classical" subduction zone must be involved.

\section{Appendix A}

[64] Table A1 presents averages of mineral compositions of 27 wehritic rocks from the Wadi Haymiliyah. It is based on about 2000 single electron microprobe analyses performed in the Institut für Mineralogie at the Leibniz University of Hannover. For details of the analytical conditions, see text.

\section{Acknowledgments}

[65] We acknowledge the support of the Universities of Hannover and Montpellier by the PROCOPE program financed by German DAAD and French EGIDE, as well as the friendly cooperation established in Oman with the Directorate of Minerals of the Ministry of Commerce and Industry (responsibility of Salim Al-Busaidi). We would also like to thank two anonymous reviewers for helpful comments on the manuscript. Valuable editorial advice from V. Salters is acknowledged. Funding for this research was provided by grants from the Deutsche Forschungsgemeinschaft (KO 1723/4; KO 1723/6).

\section{References}

Adachi, Y., and S. Miyashita (2003), Geology and petrology of the plutonic complexes in the Wadi Fizh area: Multiple magmatic events and segment structure in the northern Oman ophiolite, Geochem. Geophys. Geosyst., 4(9), 8619, doi:10.1029/2001GC000272.

Alabaster, T., J. Pearce, and J. Malpas (1982), The volcanic stratigraphy and petrogenesis of the Oman ophiolite complex, Contrib. Mineral. Petrol., 81, 168-183, doi:10.1007/ BF00371294.

Almeev, R., F. Holtz, J. Koepke, F. Parat, and R. Botcharnikov (2007), The effect of $\mathrm{H}_{2} \mathrm{O}$ on olivine crystallization in MORB: Experimental calibration at $200 \mathrm{MPa}, A m$. Mineral., 92, 670-674, doi:10.2138/am.2007.2484.

Anders, E., and N. Grevesse (1989), Abundances of the elements: Meteoritic and solar, Geochim. Cosmochim. Acta, 53, 197-214, doi:10.1016/0016-7037(89)90286-X.
Andersen, D. J., D. H. Lindsley, and P. M. Davidson (1993), QUILF-A Pascal program to assess equilibria among FeMg-Mn-Ti oxides, pyroxenes, olivine, and quartz, Comput. Geosci., 19, 1333-1350, doi:10.1016/0098-3004(93)90033-2.

Arai, S., and Y. Takemoto (2007), Mantle wehrlite from Hess Deep as a crystal cumulate from an ultra-depleted primary melt in East Pacific Rise, Geophys. Res. Lett., 34, L08302, doi:10.1029/2006GL029198.

Bagci, U., O. Parlak, and V. Hock (2005), Whole-rock and mineral chemistry of cumulates from the Kizildag (Hatay) ophiolite (Turkey): Clues for multiple magma generation during crustal accretion in the southern Neotethyan ocean, Mineral. Mag., 69, 53-76, doi:10.1180/0026461056910234.

Beard, A. D., H. Downes, P. R. D. Mason, and V. R. Vetrin (2007), Depletion and enrichment processes in the lithospheric mantle beneath the Kola Peninsula (Russia): Evidence from spinel lherzolite and wehrlite xenoliths, Lithos, 94, 1-24, doi:10.1016/j.lithos.2006.02.002.

Benn, K., A. Nicolas, and I. Reuber (1988), Mantle-crust transition zone and origin of wehrlitic magmas: Evidence from the Oman ophiolite, Tectonophysics, 151, 75-85, doi:10.1016/ 0040-1951(88)90241-7.

Berndt, J., C. Liebske, F. Holtz, M. Freise, M. Nowak, D. Ziegenbein, D. Hurkuck, and J. Koepke (2002), A combined rapid-quench and $\mathrm{H} 2$-membrane setup for internally heated pressure vessels: Description and application for water solubility in basaltic melts, Am. Mineral., 87, 1717-1726.

Berndt, J., J. Koepke, and F. Holtz (2005), An experimental investigation of the influence of water and oxygen fugacity on differentiation of MORB at $200 \mathrm{MPa}, J$. Petrol., 46, 135-167, doi:10.1093/petrology/egh066.

Bosch, D. (1991), Introduction d'eau mer dans le diapir mantellique de Zabargad (Mer Rouge) d'après les isotopes du $\mathrm{Sr}$ et du Nd, C. R. Acad. Sci., Ser. II, 313, 46-49.

Bosch, D., M. Jamais, F. Boudier, A. Nicolas, J.-M. Dautria, and P. Agrinier (2004), Deep and high-temperature hydrothermal circulation in the Oman ophiolite-Petrological and isotopic evidence, J. Petrol., 45, 1181-1208, doi:10.1093/ petrology/egh010.

Botcharnikov, R. E., J. Koepke, F. Holtz, C. McCammon, and M. Wilke (2005), The effect of water activity on the oxidation and structural state of $\mathrm{Fe}$ in a ferro-basaltic melt, Geochim. Cosmochim. Acta, 69, 5071-5085, doi:10.1016/j.gca. 2005.04.023.

Boudier, F., and A. Nicolas (2007), Comment on "Dating the geologic history of Oman's Semail ophiolite: Insights from U-Pb geochronology" by C. J. Warren, R. R. Parrish, D. J. Waters and M. P. Searle, Contrib. Mineral. Petrol., 154, 111-113, doi:10.1007/s00410-007-0189-5.

Boudier, F., J. L. Bouchez, A. Nicolas, M. Cannat, G. Ceuleneer, M. Misseri, and R. Montigny (1985), Kinematics of oceanic thrusting in the Oman ophiolite-Model of plate convergence, Earth Planet. Sci. Lett., 75, 215-222, doi:10.1016/ 0012-821X(85)90103-7.

Boudier, F., M. Godard, and C. Armbruster (2000), Significance of gabbronorite occurrence in the crustal section of the Semail ophiolite, Mar. Geophys. Res., 21, 307-326, doi:10.1023/A:1026726232402.

Burke, W. H., R. E. Denison, E. A. Hetherington, R. B. Koepnick, H. F. Nelson, and J. B. Otto (1982), Variation of seawater ${ }^{87} \mathrm{Sr} /{ }^{86} \mathrm{Sr}$ throughout Phanerozoic time, Geology, 10, 516-519, doi:10.1130/0091-7613(1982)10<516: VOSSTP $>2.0 . \mathrm{CO} ; 2$.

Burnham, W. C. (1979), The importance of volatile constituents, in The Evolution of the Igneous Rocks: Fiftieth Anni- 
versary Perspectives, edited by H. S. Yoder, pp. 439-482, Princeton Univ. Press, Princeton, N. J.

Canales, J. P., R. S. Detrick, D. R. Toomey, and W. S. D. Wilcock (2003), Segment-scale variations in the crustal structure of 150-300 kyr old fast spreading oceanic crust (East Pacific Rise, $8^{\circ} 15^{\prime} \mathrm{N}-10^{\circ} 5^{\prime} \mathrm{N}$ ) from wide-angle seismic refraction profiles, Geophys. J. Int., 152, 766-794, doi:10.1046/j.1365-246X.2003.01885.x.

Cannat, M., et al. (1995), Thin crust, ultramafic exposures, and rugged faulting patterns at the Mid-Atlantic Ridge $\left(22^{\circ}-\right.$ $\left.24^{\circ} \mathrm{N}\right)$, Geology, 23, 49-52, doi:10.1130/0091-7613(1995) $023<0049$ :TCUEAR $>2.3$.CO;2.

Coleman, R. G., and M. M. Donato (1979), Oceanic plagiogranite revisited, in Trondhjemites, Dacites, and Related Rocks, edited by F. Barker, pp. 149-167, Elsevier, Amsterdam.

Coogan, L. A., R. N. Wilson, K. M. Gillis, and C. J. MacLeod (2001), Near-solidus evolution of oceanic gabbros: Insights from amphibole geochemistry, Geochim. Cosmochim. Acta, 65, 4339-4357, doi:10.1016/S0016-7037(01)00714-1.

Danyushevsky, L. V. (2001), The effect of small amounts of $\mathrm{H}_{2} \mathrm{O}$ crystallisation of mid-ocean ridge and backarc basin magmas, J. Volcanol. Geotherm. Res., 110, 265-280, doi:10.1016/S0377-0273(01)00213-X.

Dixon, J. E., L. Leist, C. H. Langmuir, and J. Schilling (2002), Recycled dehydrated lithosphere observed in plume-influenced mid-ocean-ridge basalt, Nature, 420, 385-389, doi:10.1038/nature01215.

Einaudi, F., M. Godard, P. Pezard, J. J. Cocheme, C. Coulon, T. Brewer, and P. Harvey (2003), Magmatic cycles and formation of the upper oceanic crust at spreading centers: Geochemical study of a continuous extrusive section in the Oman ophiolite, Geochem. Geophys. Geosyst., 4(6), 8608, doi:10.1029/2002GC000362.

Ernewein, M., C. Pflumio, and H. Whitechurch (1988), The death of an accretion zone as evidenced by the magmatic history of the Sumail ophiolite (Oman), Tectonophysics, 151, 247-274, doi:10.1016/0040-1951(88)90248-X.

Ernst, W. G., and J. Liu (1998), Experimental phaseequilibrium study of Al- and Ti-contents of calcic amphibole in MORB - A semiquantitative thermobarometer, Am. Mineral., 83, 952-969.

Feig, S., J. Koepke, and J. Snow (2006), Effect of water on tholeiitic basalt phase equilibria: An experimental study under oxidizing conditions, Contrib. Mineral. Petrol., 152, 611-638, doi:10.1007/s00410-006-0123-2.

Gaetani, G. A., T. L. Grove, and W. B. Bryan (1993), The influence of water on the petrogenesis of subduction-related igneous rocks, Nature, 365, 332-334, doi:10.1038/ $365332 \mathrm{a} 0$.

Gillis, K. M., and L. A. Coogan (2002), Anatectic migmatites from the roof of an ocean ridge magma chamber, J. Petrol., 43, 2075-2095, doi:10.1093/petrology/43.11.2075.

Girardeau, J., and J. Francheteau (1993), Plagioclase-wehrlites and peridotites on the East Pacific Rise (Hess Deep) and the Mid-Atlantic Ridge (DSDP Site 334)—Evidence for magma percolation in the oceanic upper mantle, Earth Planet. Sci. Lett., 115, 137-149, doi:10.1016/0012-821X(93)90218-X.

Godard, M., J.-M. Dautria, and M. Perrin (2003), Geochemical variability of the Oman ophiolite lavas: Relationship with spatial distribution and paleomagnetic directions, Geochem. Geophys. Geosyst., 4(6), 8609, doi:10.1029/2002GC000452.

Hacker, B. R., J. L. Mosenfelder, and E. Gnos (1996), Rapid emplacement of the Oman ophiolite: Thermal and geochronologic constraints, Earth Planet. Sci. Lett., 15, 1230-1247.
Hart, S. R., and T. Dunn (1993), Experimental cpx/melt partitioning of 24 trace elements, Contrib. Mineral. Petrol., 113, 1-8, doi:10.1007/BF00320827.

Hart, S. R., A. J. Erlank, and E. J. D. Kable (1974), Sea floor basalt alteration: Some chemical and $\mathrm{Sr}$ isotopic effects, Contrib. Mineral. Petrol., 44, 219-230, doi:10.1007/ BF00413167.

Hellebrand, E., J. E. Snow, S. Mostefaoui, and P. Hoppe (2005), Trace element distribution between orthopyroxene and clinopyroxene in peridotites from the Gakkel Ridge: A SIMS and NanoSIMS study, Contrib. Mineral. Petrol., 150, 486-504, doi:10.1007/s00410-005-0036-5.

Holland, T., and J. Blundy (1994), Nonideal interactions in calcic amphiboles and their bearing on amphibole-plagioclase thermometry, Contrib. Mineral. Petrol., 116, 433-447, doi:10.1007/BF00310910.

Ildefonse, B., D. Blackman, B. E. John, Y. Ohara, D. J. Miller, C. J. MacLeod, and the IODP Expeditions 304-305 Scientists (2006), IODP Expeditions $304 \& 305$ characterize the lithology, structure, and alteration of an oceanic core complex, Sci. Drill., 3, 4-11.

Ishikawa, T., K. Nagaishi, and S. Umino (2002), Boninitic volcanism in the Oman ophiolite: Implications for thermal condition during transition from spreading ridge to arc, Geology, 30, 899-902, doi:10.1130/0091-7613(2002)030< 0899:BVITOO $>2.0 . \mathrm{CO} ; 2$.

Jagoutz, O., O. Muntener, P. Ulmer, T. Pettke, J. P. Burg, H. Dawood, and S. Hussain (2007), Petrology and mineral chemistry of lower crustal intrusions: The Chilas Complex, Kohistan (NW Pakistan), J. Petrol., 48, 1895-1953, doi:10.1093/petrology/egm044.

Johnson, M. C., A. T. Anderson, and M. J. Rutherford (1994), Pre-eruptive volatile contents of magmas, in Volatiles in Magmas, Rev. Mineral, vol. 30, edited by M. R. Carroll and J. R. Holloway, pp. 281-330, Mineral. Soc. of Am., Washington, D. C.

Jousselin, D., and A. Nicolas (2000), The Moho transition zone in the Oman ophiolite-relation with wehrlites in the crust and dunites in the mantle, Mar. Geophys. Res., 21, 229-241, doi:10.1023/A:1026733019682.

Juteau, T., M. Beurrier, R. Dahl, and P. Nehlig (1988a), Segmentation at a fossil spreading axis: The plutonic sequence of the Wadi Haymiliyah area (Haylayn Block, Sumail Nappe, Oman), Tectonophysics, 151, 167-197, doi:10.1016/0040-1951(88)90245-4.

Juteau, T., M. Ernewein, I. Reuber, H. Whitechurch, and R. Dahl (1988b), Duality of magmatism in the plutonic sequence of the Sumail Nappe, Oman, Tectonophysics, 151, 107-135, doi:10.1016/0040-1951(88)90243-0.

Kawahata, H., M. Nohara, H. Ishizuka, S. Hasebe, and H. Chiba (2001), Sr isotope geochemistry and hydrothermal alteration of the Oman ophiolite, J. Geophys. Res., 106, 11,083-11,099, doi:10.1029/2000JB900456.

Kelemen, P. B., N. Shimizu, and V. J. M. Salters (1995), Extraction of mid-ocean ridge basalt from the upwelling mantle by focused flow of melt in dunite channels, Nature, 375, 747-753.

Kelemen, P. B., K. Hanghoj, and A. R. Greene (2004), One view of the geochemistry of subduction-related magmatic arcs, with an emphasis on primitive andesite and lower crust, in Treatise on Geochemistry, vol. 3, edited by H. D. Holland and K. K. Turekian, pp. 593-659, Elsevier, Amsterdam.

Koepke, J., S. T. Feig, J. Snow, and M. Freise (2004), Petrogenesis of oceanic plagiogranites by partial melting of gab- 
bros: An experimental study, Contrib. Mineral. Petrol., 146, 414-432, doi:10.1007/s00410-003-0511-9.

Koepke, J., S. T. Feig, and J. Snow (2005a), Late-stage magmatic evolution of oceanic gabbros as a result of hydrous partial melting: Evidence from the ODP Leg 153 drilling at the Mid-Atlantic Ridge, Geochem. Geophys. Geosyst., 6, Q02001, doi:10.1029/2004GC000805.

Koepke, J., S. T. Feig, and J. Snow (2005b), Hydrous partial melting within the lower oceanic crust, Terra Nova, 17, 286-291, doi:10.1111/j.1365-3121.2005.00613.x.

Koepke, J., J. Berndt, S. T. Feig, and F. Holtz (2007), The formation of $\mathrm{SiO}_{2}$-rich melts within the deep oceanic crust by hydrous partial melting of gabbros, Contrib. Mineral. Petrol., 153, 67-84, doi:10.1007/s00410-006-0135-y.

Koepke, J., D. M. Christie, W. Dziony, F. Holtz, D. Lattard, J. Maclennan, S. Park, B. Scheibner, T. Yamasaki, and S. Yamasaki (2008), Petrography of the dike-gabbro transition at IODP Site 1256D (equatorial Pacific): The evolution of the granoblastic dikes, Geochem. Geophys. Geosyst., 9, Q07O09, doi:10.1029/2008GC001939.

Koga, K. T., P. B. Kelemen, and N. Shimizu (2001), Petrogenesis of the crust-mantle transition zone and the origin of lower crustal wehrlite in the Oman ophiolite, Geochem. Geophys. Geosyst., 2(9), 1038, doi:10.1029/2000GC000132.

Kress, V. C., and I. S. E. Carmichael (1991), The compressibility of silicate liquidus containing $\mathrm{Fe}_{2} \mathrm{O}_{3}$ and the effect of composition, temperature, oxygen fugacity and pressure on their redox states, Contrib. Mineral. Petrol., 108, 82-92, doi:10.1007/BF00307328.

Kvassnes, A. J. S., A. H. Strand, H. Moen-Eikeland, and R. Pedersen (2004), The Lyngen Gabbro: The lower crust of an Ordovician Incipient Arc, Contrib. Mineral. Petrol., 148, 358-379, doi:10.1007/s00410-004-0609-8.

Lachize, M., J. P. Lorand, and T. Juteau (1996), Calc-alkaline differentiation trend in the plutonic sequence of the Wadi Haymiliyah section, Haylayn massif, Semail ophiolite, Oman, Lithos, 38, 207-232, doi:10.1016/0024-4937(96) 00009-6.

Le Mée, L., J. Girardeau, and C. Monnier (2004), Mantle segmentation along the Oman ophiolite fossil mid-ocean ridge, Nature, 432, 167-172, doi:10.1038/nature03075.

Lippard, S. J., A. W. Shelton, and I. G. Gass (1986), The Ophiolite of Northern Oman, Geol. Soc. Mem., vol. 11, 178 pp., Blackwell Sci., Oxford, U. K.

MacLeod, C. J., and D. A. Rothery (1992), Ridge axial segmentation in the Oman ophiolite: Evidence from along-strike variations in the sheeted dyke complex, in Ophiolites and Their Modern Oceanic Analogues, edited by L. M. Parson, B. J. Murton, and P. Browning, Geol. Soc. Spec. Publ., 60, $39-63$.

McCulloch, M. T., R. T. Gregory, G. J. Wasserburg, and H. P. Taylor (1981), Sm-Nd, $\mathrm{Rb}-\mathrm{Sr}$, and ${ }^{18} \mathrm{O} /{ }^{16} \mathrm{O}$ systematics in an oceanic crustal section: Evidence from the Samail Ophiolite, J. Geophys. Res., 86(B4), 2721-2735, doi:10.1029/ JB086iB04p02721.

Miyashiro, A. (1974), Volcanic rock series in island arcs and active continental margins, Am. J. Sci., 274, 321-355.

Nehlig, P., and T. Juteau (1988), Flow porosities, permeabilities and preliminary data on fluid inclusions and fossil thermal gradients in the crustal sequence of the Sumail Nappe, Oman, Tectonophysics, 151, 199-221, doi:10.1016/00401951(88)90246-6.

Nicolas, A. (1989), Structures of Ophiolites and Dynamics of Oceanic Lithosphere, 376 pp., Kluwer, Dordrecht, Netherlands.
Nicolas, A., and M. Rabinowicz (1988), Mantle flow pattern at oceanic spreading centres: Relation with ophiolitic and oceanic structures, in Ophiolites and Oceanic lithosphere, edited by I. G. Gass, S. J. Lippard, and A. W. Shelton, Spec. Publ. Geol. Soc., 14, 147-151.

Nicolas, A., F. Boudier, B. Ildefonse, and E. Ball (2000), Accretion of Oman and United Arab Emirates ophioliteDiscussion of a new structural map, Mar. Geophys. Res., 21, 147-179, doi:10.1023/A:1026769727917.

Nicolas, A., D. Mainprice, and F. Boudier (2003), High temperature seawater circulation throughout crust of oceanic ridges. A model derived from the Oman ophiolite, J. Geophys. Res., 108(B8), 2371, doi:10.1029/2002JB002094.

Pallister, J. S., and R. J. Knight (1981), Rare-earth element geochemistry of the Samail ophiolite near Ibra, Oman, J. Geophys. Res., 86, 2673-2697, doi:10.1029/ JB086iB04p02673.

Parkinson, I. J., R. J. Arculus, and S. M. Eggins (2003), Peridotite xenoliths from Grenada, Lesser Antilles Island Arc, Contrib. Mineral. Petrol., 146, 241-262, doi:10.1007/ s00410-003-0500-z.

Parlak, O., V. Hock, and M. Delaloye (2002), The suprasubduction zone Pozanti-Karsanti ophiolite, southern Turkey: Evidence for high-pressure crystal fractionation of ultramafic cumulates, Lithos, 65, 205-224, doi:10.1016/S00244937(02)00166-4.

Pearce, J. A., S. J. Lippard, and S. Roberts (1984), Characteristics and tectonic significance of supra-subduction zone ophiolites, in Marginal Basin Geology, edited by B. P. Kokelaar and M. J. Howells, pp. 77-94, Blackwell, London.

Peslier, A. H., D. Francis, and J. Ludden (2002), The lithospheric mantle beneath continental margins: Melting and melt-rock reaction in Canadian Cordillera xenoliths, J. Petrol., 43, 2013-2047, doi:10.1093/petrology/43.11.2013.

Pouchou, J. L., and F. Pichoir (1991), Quantitative analysis of homogeneous or stratified microvolumes applying the model "PAP," in Electron Probe Quantification, edited by K. F. J. Heinrich and D. E. Newbury, pp. 31-75, Plenum, New York.

Putirka, K. D. (2008), Thermometers and barometers for volcanic systemsRev. Mineral. Geochem., 69, 61-120, doi:10.2138/rmg.2008.69.3.

Reuber, I., P. Nehlig, and T. Juteau (1991), Axial segmentation at a fossil oceanic spreading center in the Haylayn Block (Semail Nappe, Oman) - Off-axis mantle diapir and advancing ridge tip, J. Geodyn., 13, 253-278, doi:10.1016/02643707(91)90041-C.

Shaw, C. S. J., J. Eyzaguirre, B. Fryer, and J. Gagnon (2005), Regional variations in the mineralogy of metasomatic assemblages in mantle xenoliths from the West Eifel Volcanic Field, Germany, J. Petrol., 46, 945-972, doi:10.1093/ petrology/egi006.

Shervais, J. W., D. L. Kimbrough, P. Renne, B. B. Hanan, B. Murchey, C. A. Snow, M. M. Z. Schuman, and J. Beaman (2004), Multi-stage origin of the Coast Range ophiolite, California: Implications for the life cycle of supra-subduction zone ophiolites, Int. Geol. Rev., 46, 289-315, doi:10.2747/ 0020-6814.46.4.289.

Sobolev, A. V., and M. Chaussidon (1996), $\mathrm{H}_{2} \mathrm{O}$ concentration in primary melts from supra-subduction zones and midocean ridges: Implication for $\mathrm{H}_{2} \mathrm{O}$ storage and recycling in the mantle, Earth Planet. Sci. Lett., 137, 45-55, doi:10.1016/0012-821X(95)00203-O.

Sobolev, A. V., and N. Shimizu (1993), Ultra-depleted primary melt included in an olivine from the Mid-Atlantic Ridge, Nature, 363, 151-154, doi:10.1038/363151a0. 
Tilton, G. R., C. A. Hopson, and J. E. Wright (1981), Uranium-lead isotopic ages of the Samail Ophiolite, Oman, with applications to tethyan ocean ridge tectonics, J. Geophys. Res., 86(B4), 2763-2775, doi:10.1029/JB086iB04p02763.

Toplis, M. J. (2005), The thermodynamicsof iron and magnesium partitioning between olivine and liquid: Criteria for assessing and predicting equilibrium in natural and experimental systems J. Petrol., 149, 22-39.

Warren, C. J., R. R. Parrish, D. J. Waters, and M. P. Searle (2005), Dating the geologic history of Oman's Semail ophiolite: Insights from U-Pb geochronology, Contrib. Mineral. Petrol., 150, 403-422, doi:10.1007/s00410-005-0028-5.
Warren, C. J., M. P. Searle, R. R. Parrish, and D. J. Waters (2007), Reply to comment by F. Boudier and A. Nicolas on "Dating the geologic history of Oman's Semail ophiolite: Insights from U-Pb geochronology" by C. J. Warren, R. R. Parrish, M. P. Searle and D. J. Waters, Contrib. Mineral. Petrol., 154, 115-118, doi:10.1007/s00410-007-0182-z.

Yamasaki, T., J. Maeda, and T. Mizuta (2006), Geochemical evidence in clinopyroxenes from gabbroic sequence for two distinct magmatisms in the Oman ophiolite, Earth Planet. Sci. Lett., 251, 52-65, doi:10.1016/j.epsl.2006.08.027.

Yamazaki, S., and S. Miyashita (2008), Geochemistry of High$\mathrm{Ca}$ boninite dike swarms and the related plutonic rocks in the Oman Ophiolite, Eos. Trans. AGU, 89(53), Fall Meet. Suppl., Abstract T21A-1939. 